\title{
Vegetation Response to Climate Change in Alaska: Examples From the Fossil Record
}

Open-File Report 2007-1096 


\section{U.S. Department of the Interior DIRK KEMPTHORNE, Secretary}

\section{U.S. Geological Survey \\ Mark D. Myers, Director}

\section{U.S. Geological Survey, Reston, Virginia: 2007}

For product and ordering information:

World Wide Web: http://www.usgs.gov/pubprod

Telephone: 1-888-ASK-USGS

For more information on the USGS - the Federal source for science about the Earth, its natural and living resources, natural hazards, and the environment:

World Wide Web: http://www.usgs.gov

Telephone: 1-888-ASK-USGS

Any use of trade, firm, or product names is for descriptive purposes only and does not imply endorsement by the U.S. Government.

Although this report is in the public domain, permission must be secured from the individual copyright owners to reproduce any copyrighted materials contained within this report.

Suggested citation:

Ager, Thomas, 2007, Vegetation response to climate change in Alaska: Examples from the fossil record: U.S. Geological Survey Open-File Report 2007-1096, 44 p. 


\title{
PREFACE
}

\section{Vegetation response to climate change in Alaska: Examples from the fossil record}

\author{
Thomas A. Ager \\ U.S. Geological Survey
}

This report was presented as an invited paper at the Fish \& Wildlife Service Climate Forum held in Anchorage, Alaska on February 21-23, 2007. The purpose of the talk was to provide some examples of past climate changes that appear to have caused significant responses in Alaskan vegetation. These examples are based on interpretations of dated fossil assemblages (pollen, spores and plant macrofossils) collected and interpreted by U.S. Geological Survey and collaborating scientists from other scientific organizations during the past several decades.

This presentation has been made available for public distribution at the request of the Fish \& Wildlife Service Climate Change Forum organizers. The original talk, given as a PowerPoint presentation, has been converted to U.S. Geological Survey Open-File Report (OF 2007-1096). This presentation received U.S. Geological Survey Bureau Approval for public release on April 2, 2007.

Additional information about the subject matter in this presentation may be obtained by contacting the author (address below).

\author{
Dr. Thomas Ager \\ Research Geologist \\ U.S. Geological Survey \\ Mail Stop 980 \\ Box 25046, Denver Federal Center \\ Denver, CO 80225 \\ (303)236-5728 \\ tager@usgs.gov
}




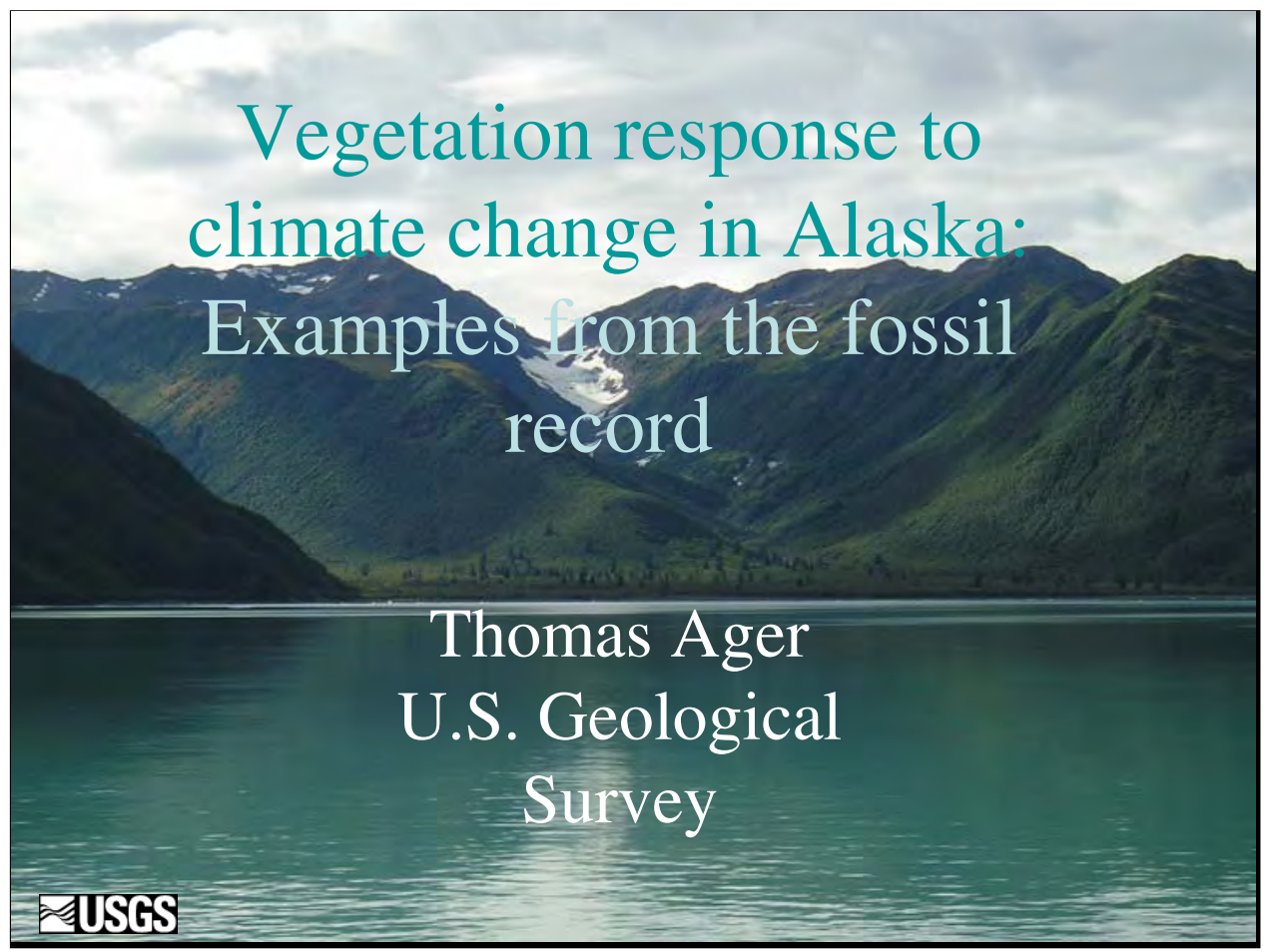

Title photo: Vegetation response to climate change in Alaska: Examples from the fossil record.

Contact: Dr. Thomas Ager, Research Geologist

U.S. Geological Survey, Mail Stop 980, Box 25046 Denver Federal Center, Denver, CO 80225

(303)236-5728

tager@usgs.gov

Photo by Thomas Ager, USGS. 


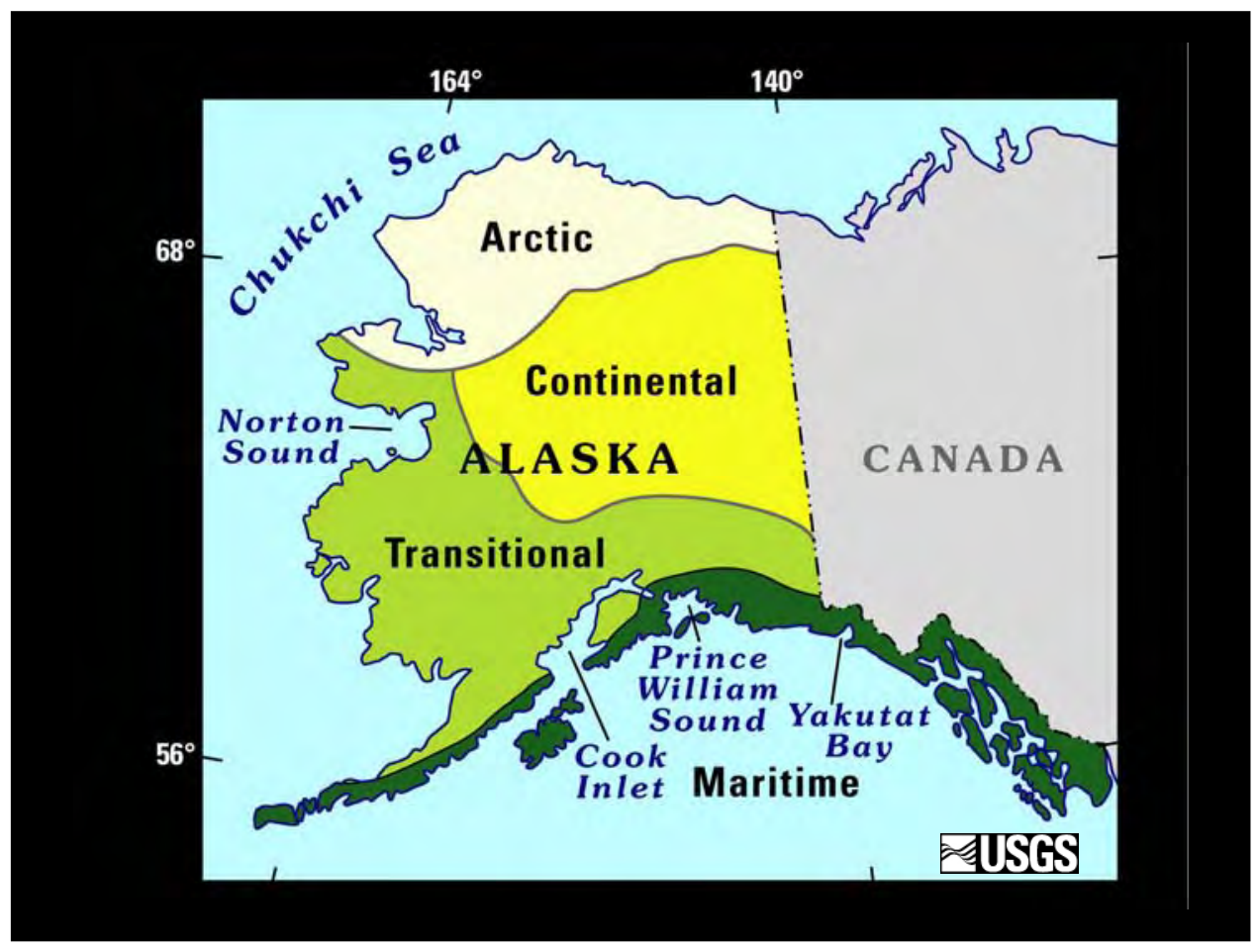

Map of present climate zones of Alaska (after Pewe, 1975). Distribution of dominant climate types in Alaska reflects influences of latitude, topography, and proximity to oceanic air masses, especially from the North Pacific. The highly continental climate of interior Alaska is the result of distance from oceanic moisture sources and the precipitation shadow effects of the Brooks Range to the north and the Alaska Range and other high mountain ranges to the south.

Reference: Pewe, T.L., 1975, Quaternary geology of Alaska: U.S. Geological Survey Professional Paper 835, 1 plate, 2 tables, 145 p. 


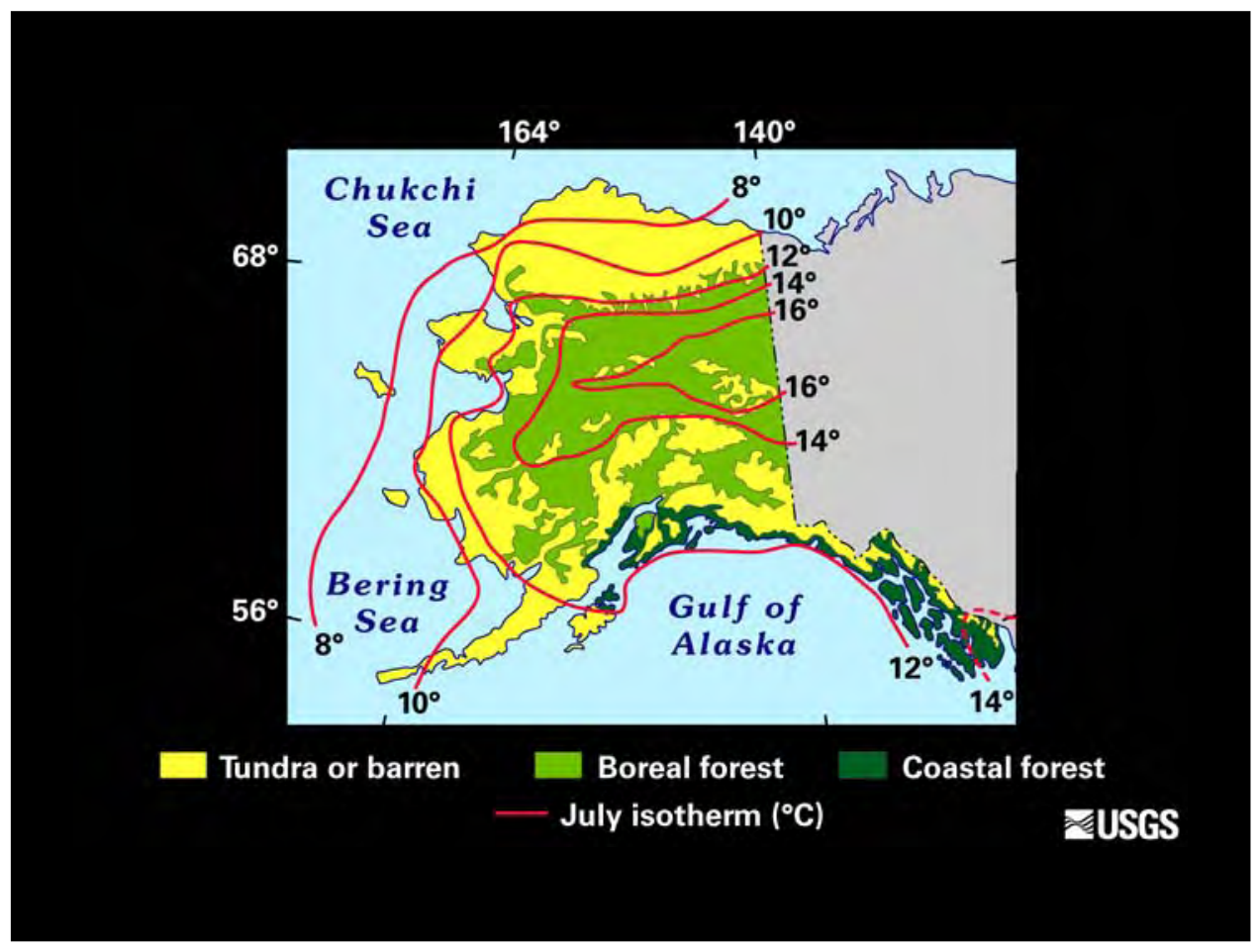

Present-day vegetation of Alaska can be divided into three broad types: tundra, boreal forest, and coastal forest (modified from Viereck and Little, 1972). Tundra types include alpine, arctic, and "subarctic" forms. Boreal forest covers lowlands of interior and inland south-central Alaska (white spruce, black spruce, larch, balsam poplar, aspen, paper birch, willow, and alder). Coastal forest is associated with maritime climates of the Gulf of Alaska. In southeastern Alaska, this forest includes western hemlock, shore pine, Sitka spruce, mountain hemlock, red cedar, yellow cedar, and a few other species.

Reference: Viereck, L.A., and Little, E.L., Jr., 1972, Alaska trees and shrubs: Washington, D.C., USDA Forest Service Agriculture Handbook no. 410,265 p. 


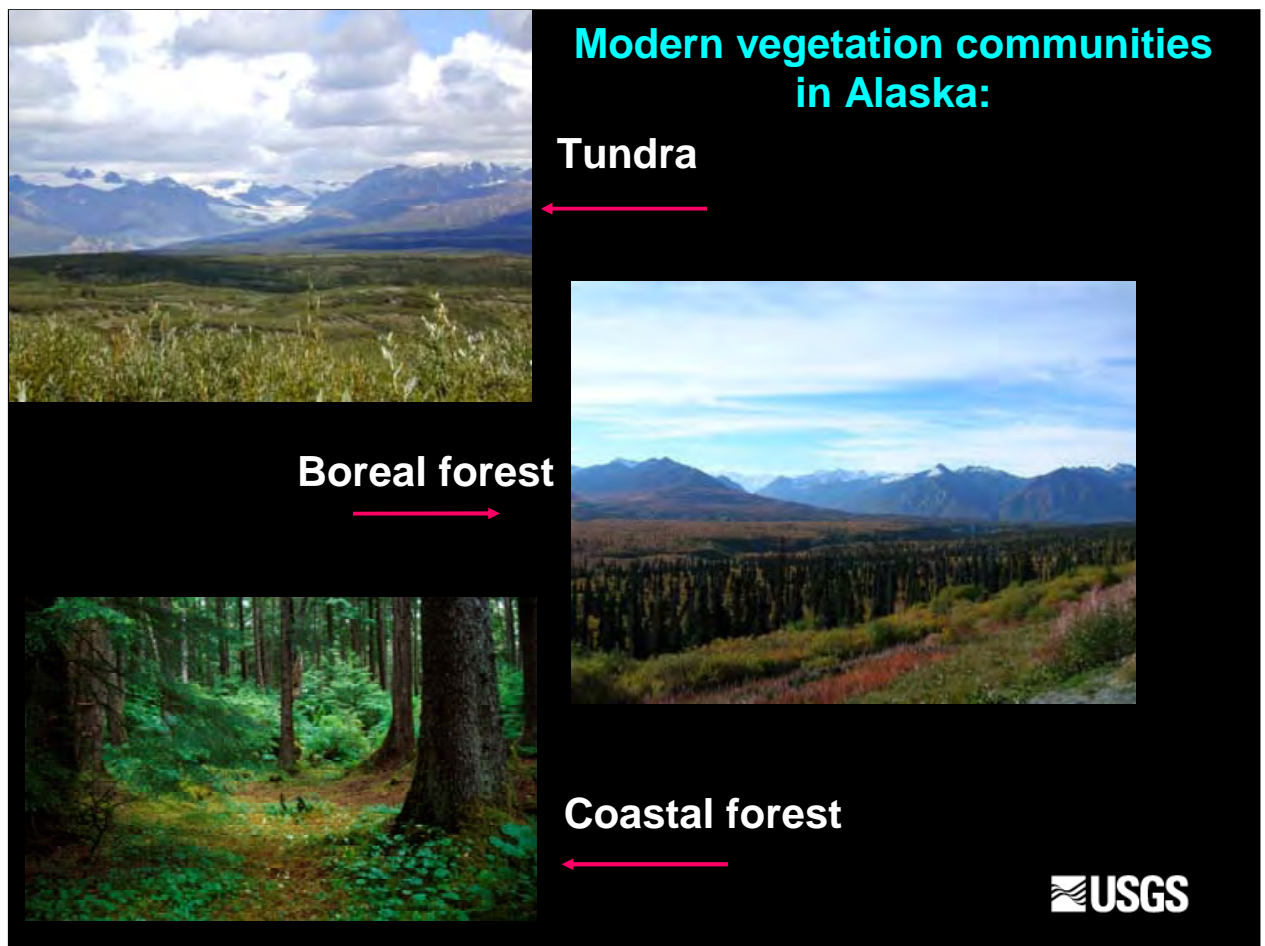

This shows examples of the three modern vegetation types of Alaska: tundra, boreal forest, and coastal forest.

Figure courtesy of Dr. Dan Muhs, USGS. 


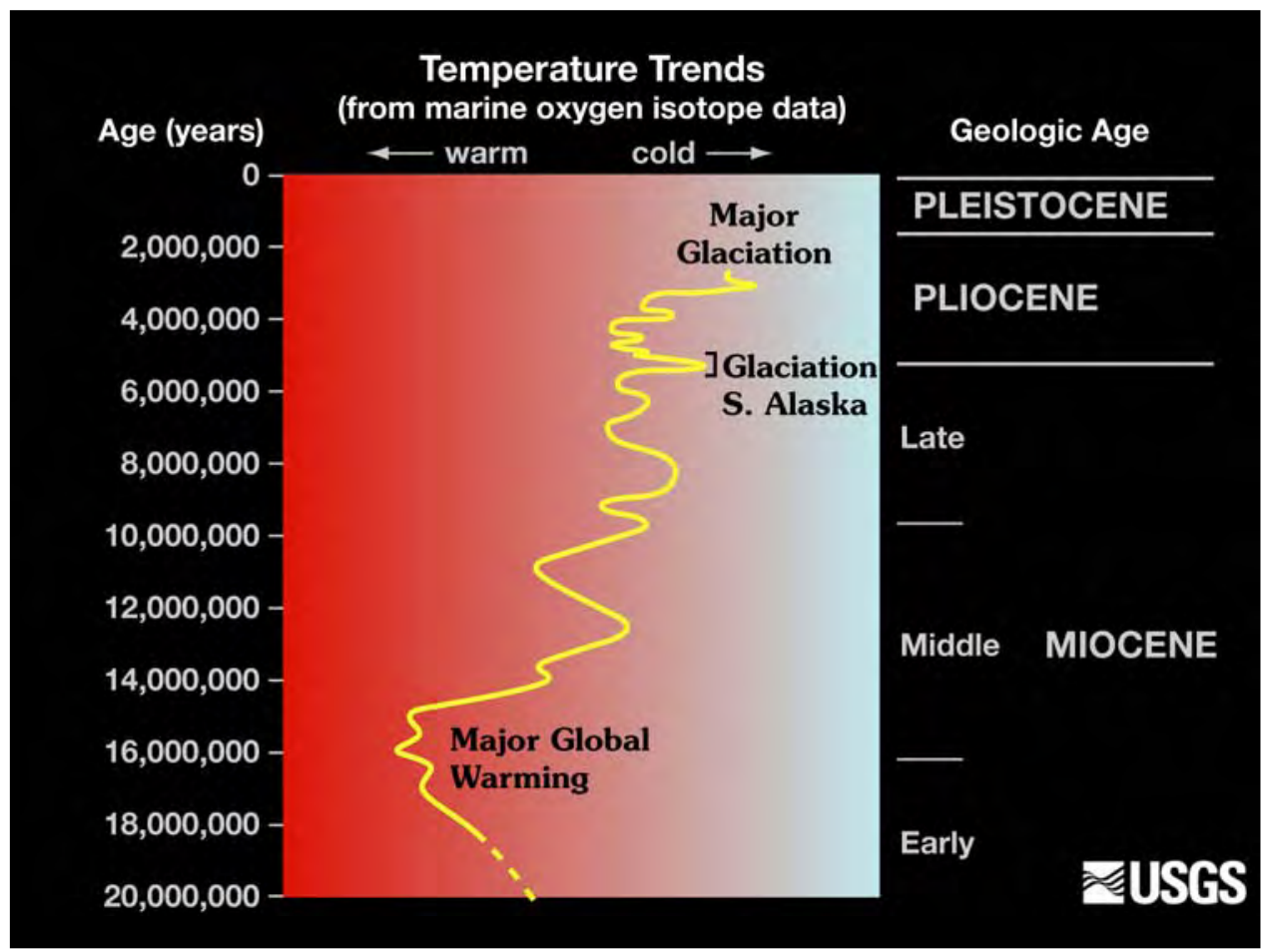

An extreme warming event that had profound effects on Alaskan vegetation occurred during the middle Miocene, when global climates became much warmer than today. By examining fossil evidence from dated exposures of Miocene sediments, it is possible to reconstruct in considerable detail the nature of Miocene vegetation of northwestern North America. (Note: the age of the base of the Miocene is 23 million years old, and this chart does not show the record for the earliest Miocene. Also not shown: the Holocene, representing the last 10,000 years of history following the Pleistocene.

Reference: Ager, T.A., 1997, How does climate change influence Alaska's vegetation: insights from the fossil record: U.S. Geological Survey Fact Sheet FS-071-97. 


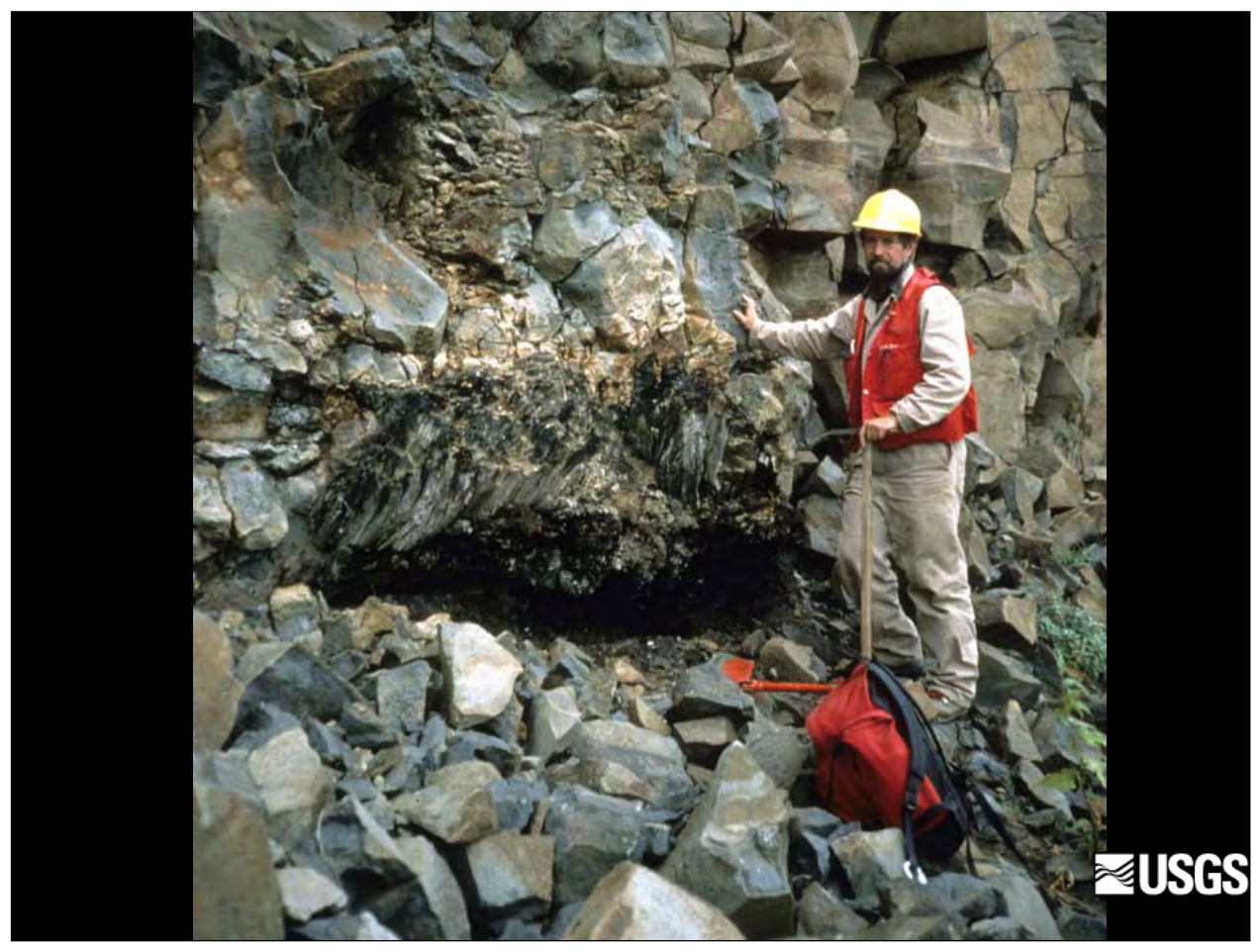

Reconstructing Miocene and Pliocene vegetation changes involves paleobotany, palynology, geochronology, and stratigraphy. In this photo, Dr. James White from the Geological Survey of Canada is standing next to a Sequoia (redwood) stump (unfossilized) charred and buried by a middle Miocene age basalt flow about 16 million years old. The stump is in situ, and its roots penetrate well-preserved peat that contains abundant pollen and spores. This site is north of the Arctic circle in northeastern Alaska, in the Porcupine River canyon. Dated plant fossil evidence from this site and many other sites in Alaska is being used to reconstruct the broad outlines of vegetation changes in northwestern North America during the Miocene, Pliocene, and Quaternary. Today, Sequoia trees grow no farther north than southern Oregon.

Photo by Dr. Thomas Ager, USGS. 


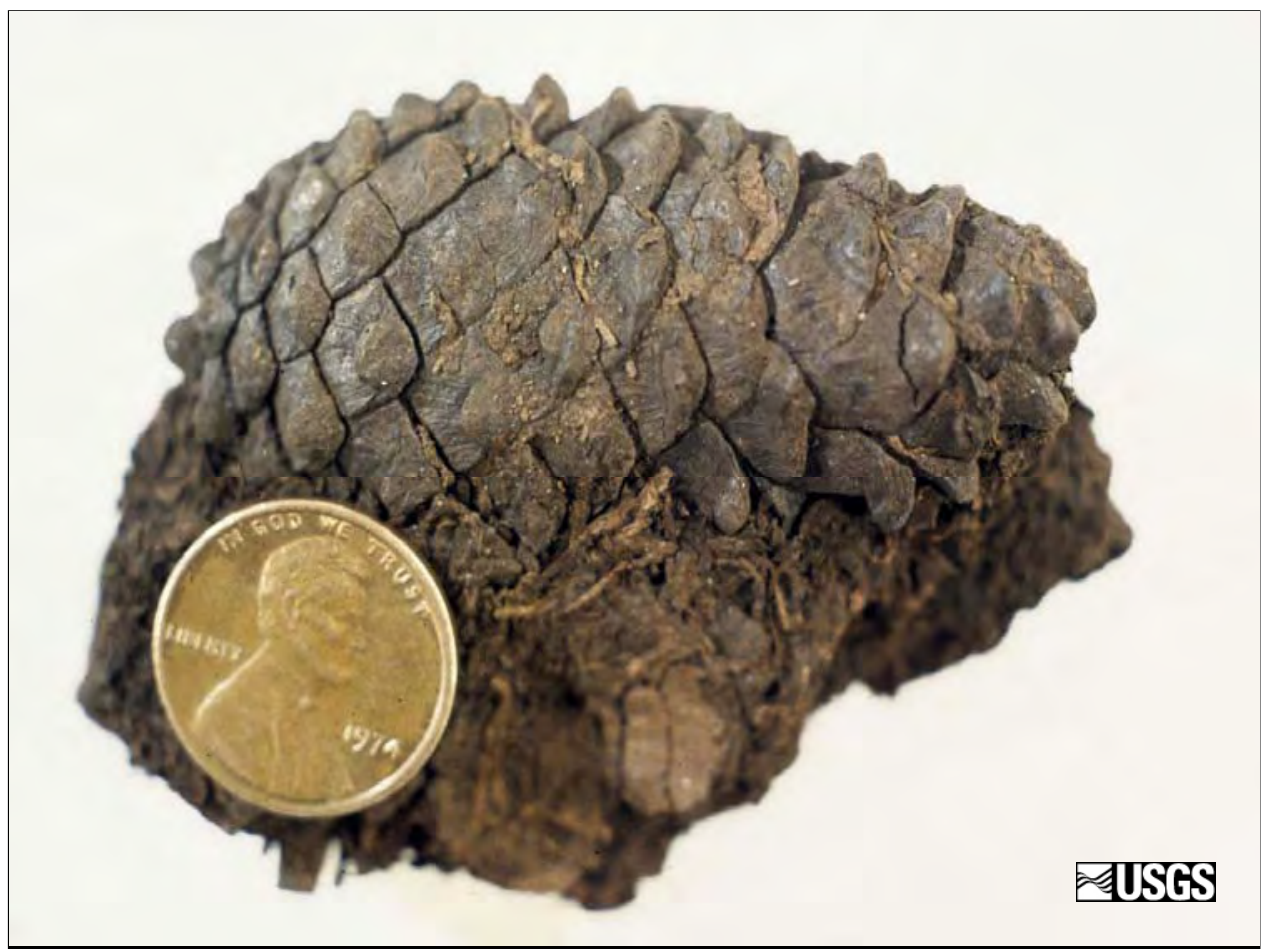

Pine cone preserved in peat layers from between basalt lava flows, Porcupine River canyon, northeastern Alaska. Age is middle Miocene, about 16 million years old. This cone is probably from an ancestral form of lodgepole pine that now grows in western Canada and southeastern Alaska. Pollen from this peat and other peat layers contains a rich assemblage of northern hardwood and conifer species. This assemblage suggests a cool temperate climate for interior and southcentral Alaska during the middle Miocene.

Photo by Dr. Thomas Ager, USGS. 


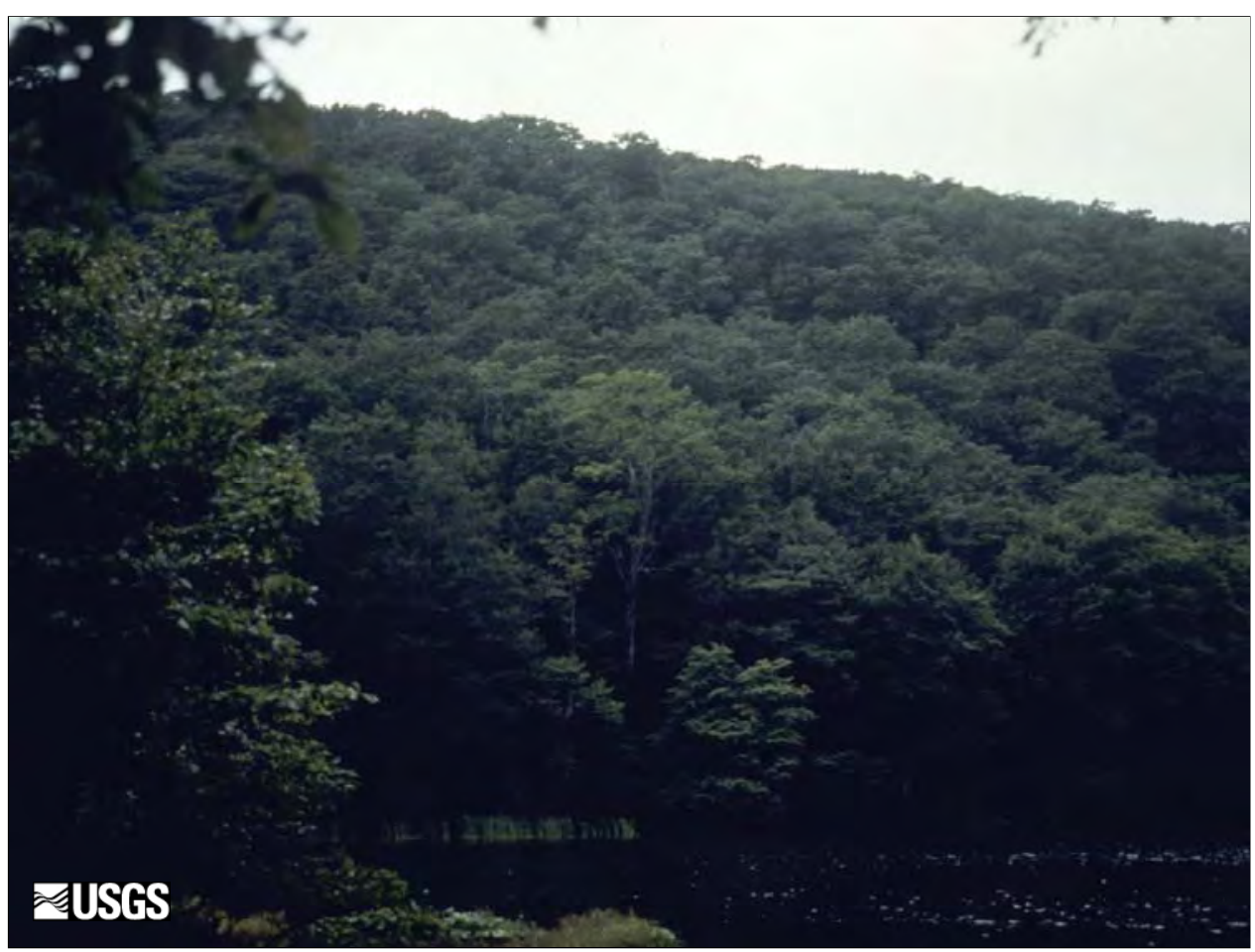

Pollen assemblages and plant macrofossils from interior and southcentral Alaska indicate that during the middle Miocene global warming event, northern hardwood forests with a rich assemblage of conifers covered much of Alaska. Modern-day forests that contain many of the tree species growing in Alaska during the middle Miocene can be found in China, Korea, northern Japan, the Northeastern United States, and the Pacific Northwest of the United States. This photo is of a northern hardwood forest in northern Japan.

Photo by Dr. Jack Wolfe, USGS (deceased). 


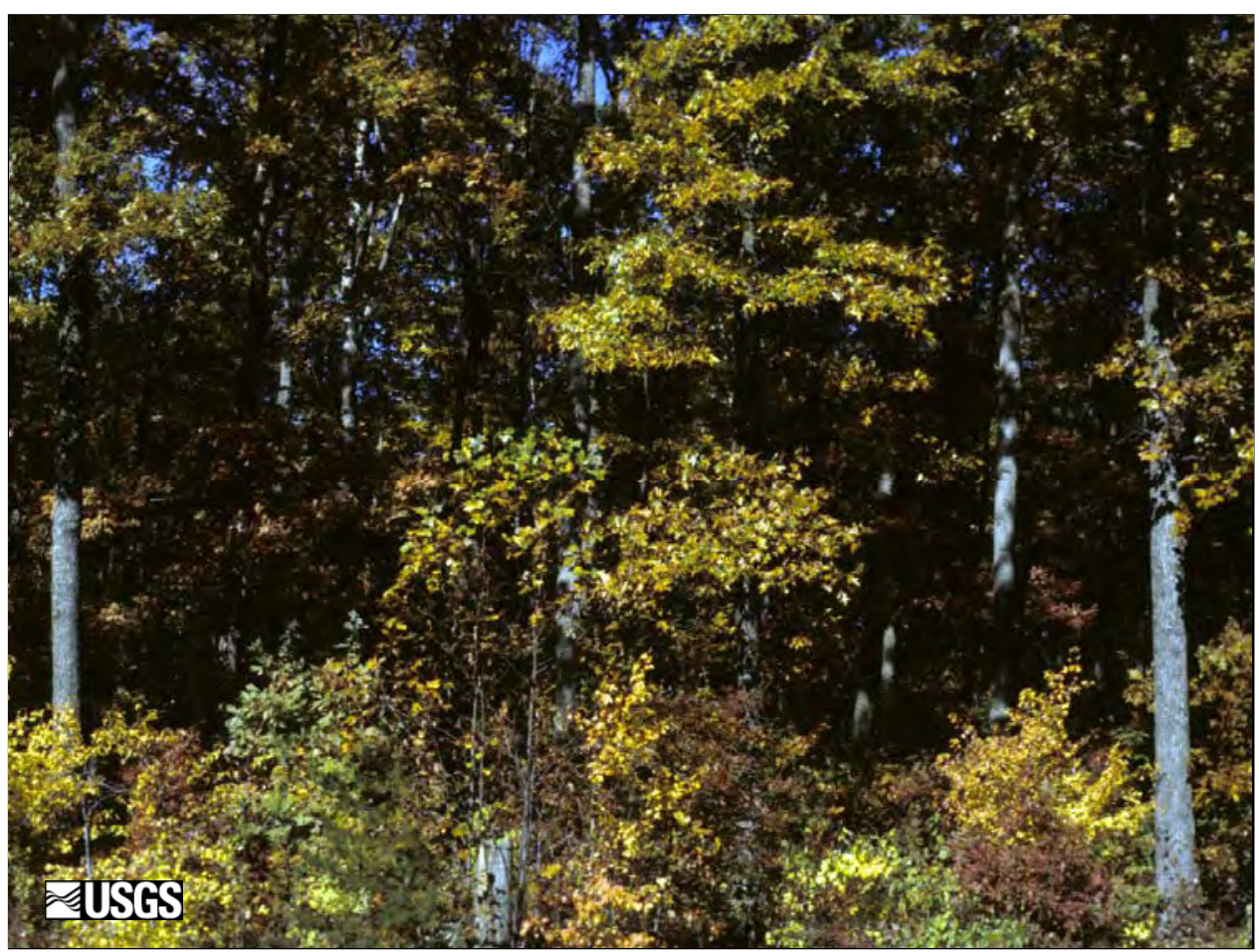

Another modern near analog for Alaskan forest vegetation during the middle Miocene can be found today in Pennsylvania, Delaware, New York, Maryland, Virginia and adjacent States. Pollen and plant macrofossils from Alaska indicate that northern hardwoods such as hickory, chestnut, oak, basswood, sweetgum, ironwood, holly, beech, elm, wing-nut (found in Asia today), ash, and many other broadleaf species grew there during the middle Miocene. Conifers that grew in interior and south-central Alaska during the middle Miocene included pine, spruce, hemlock, fir, Douglas fir, redwood, and dawn redwood. Mean annual temperature in interior Alaska was probably about 10 to 12 degrees Celsius, compared with mean annual temperatures of about - 3 degrees Celsius in Fairbanks and - 8 degrees Celsius at Fort Yukon today. Mean annual precipitation was probably at least twice or three times higher during the middle Miocene than it is now in the interior.

Photo by Dr. Thomas Ager, USGS. 


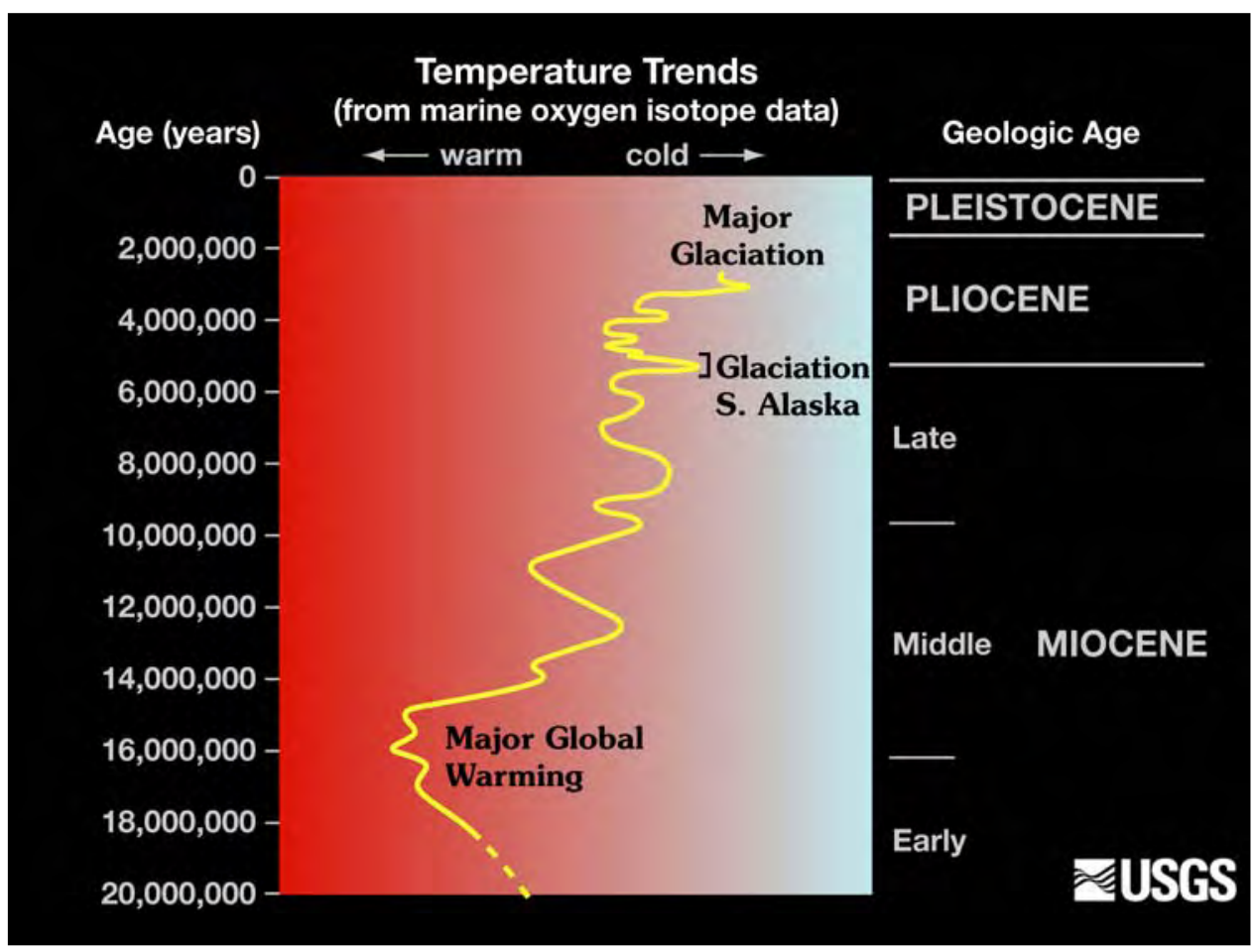

A long interval of oscillating climates followed the middle Miocene warming event, with a gradual cooling trend that progressively eliminated most of the northern hardwoods from Alaska, leaving behind a conifer-dominated forest vegetation that was far richer in tree types than now exist in the interior. Glaciation of Greenland began about 7-8 million years ago. Expansion of glacial ice in Antarctica occurred about 14 million years ago. (Initial glaciation in east Antarctica began during the late Eocene.) 


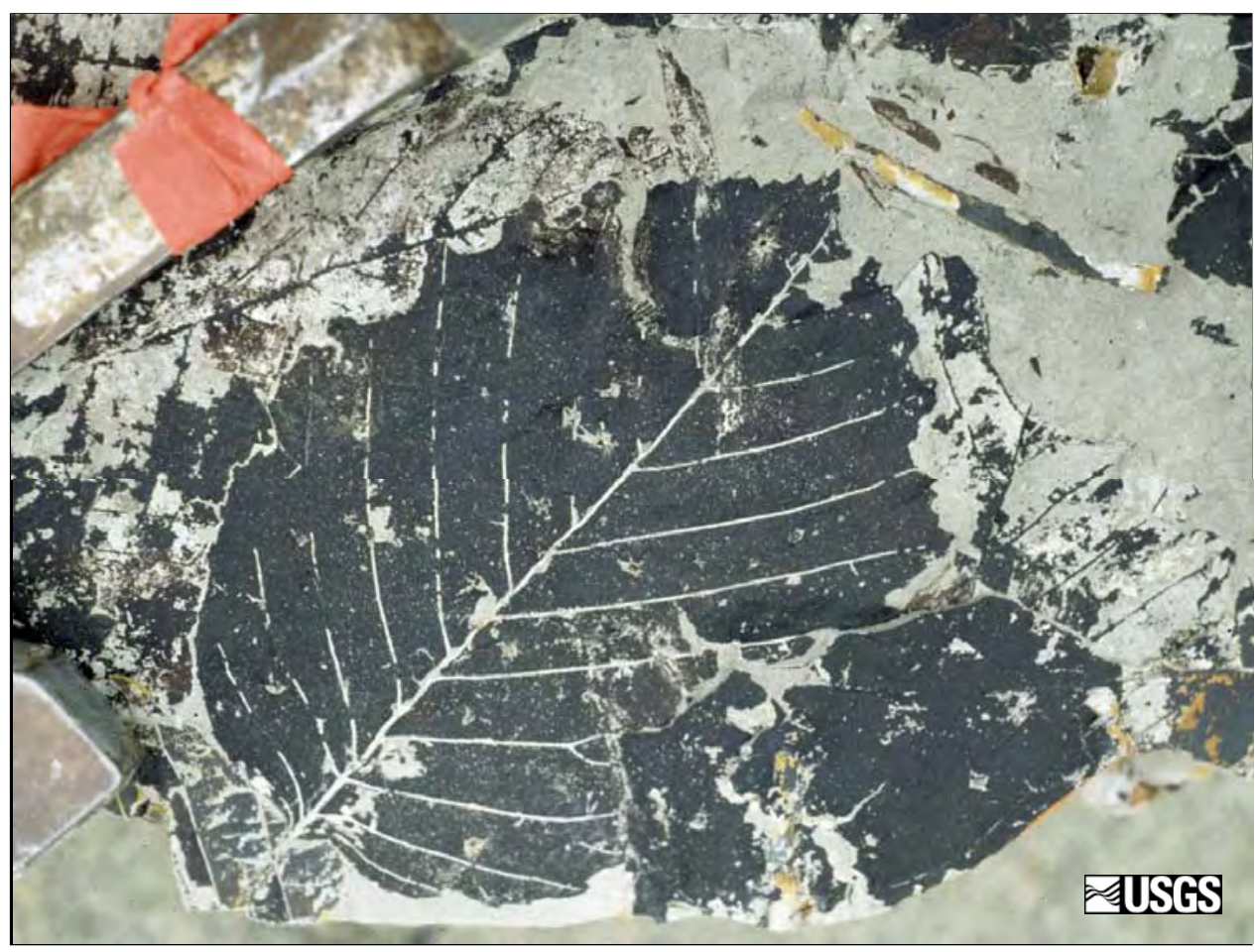

During the late Miocene, many broadleaf tree and shrub species associated with cool temperate climates of the mid-Miocene warming were eliminated from high latitude North America and Northeast Asia by cold climate oscillations. Surviving broadleaf trees and shrubs included alders (a fossil leaf of which is shown here, from upper Miocene rocks in the Homer area of Cook Inlet, south-central Alaska).

Photo by Dr. Thomas Ager, USGS. 


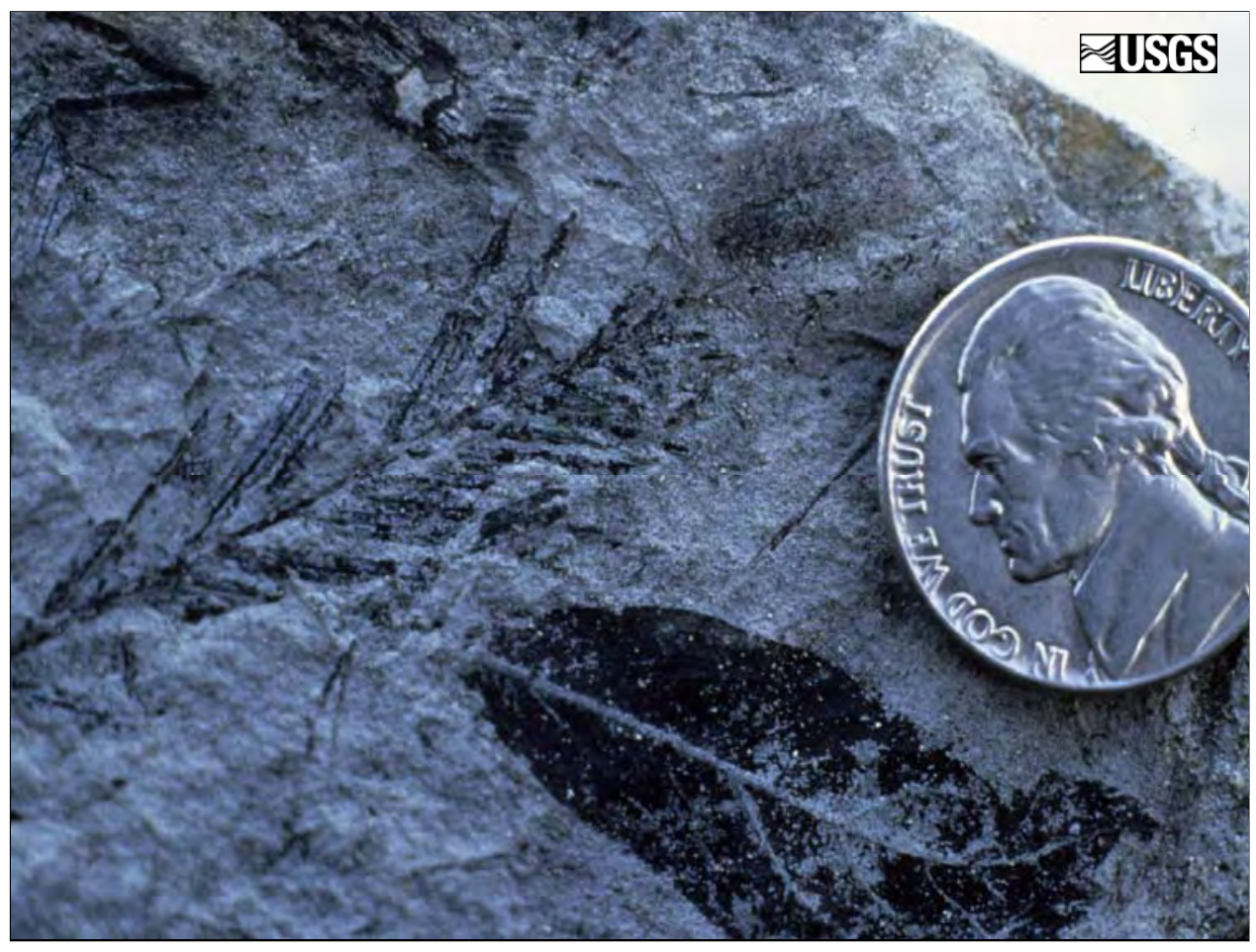

Other late Miocene plant fossils from interior and south-central Alaska include specimens of willow, fir, pine, and dawn redwood. This rock specimen includes a fossil willow leaf below the coin, and a conifer twig with needles attached (to the left of the coin). Some of the hardier tree types from the Northern Hardwood flora persisted in Alaska, but in diminishing importance (for example, elm, hazelnut, wing-nut).

Photo by Dr. Thomas Ager, USGS. 


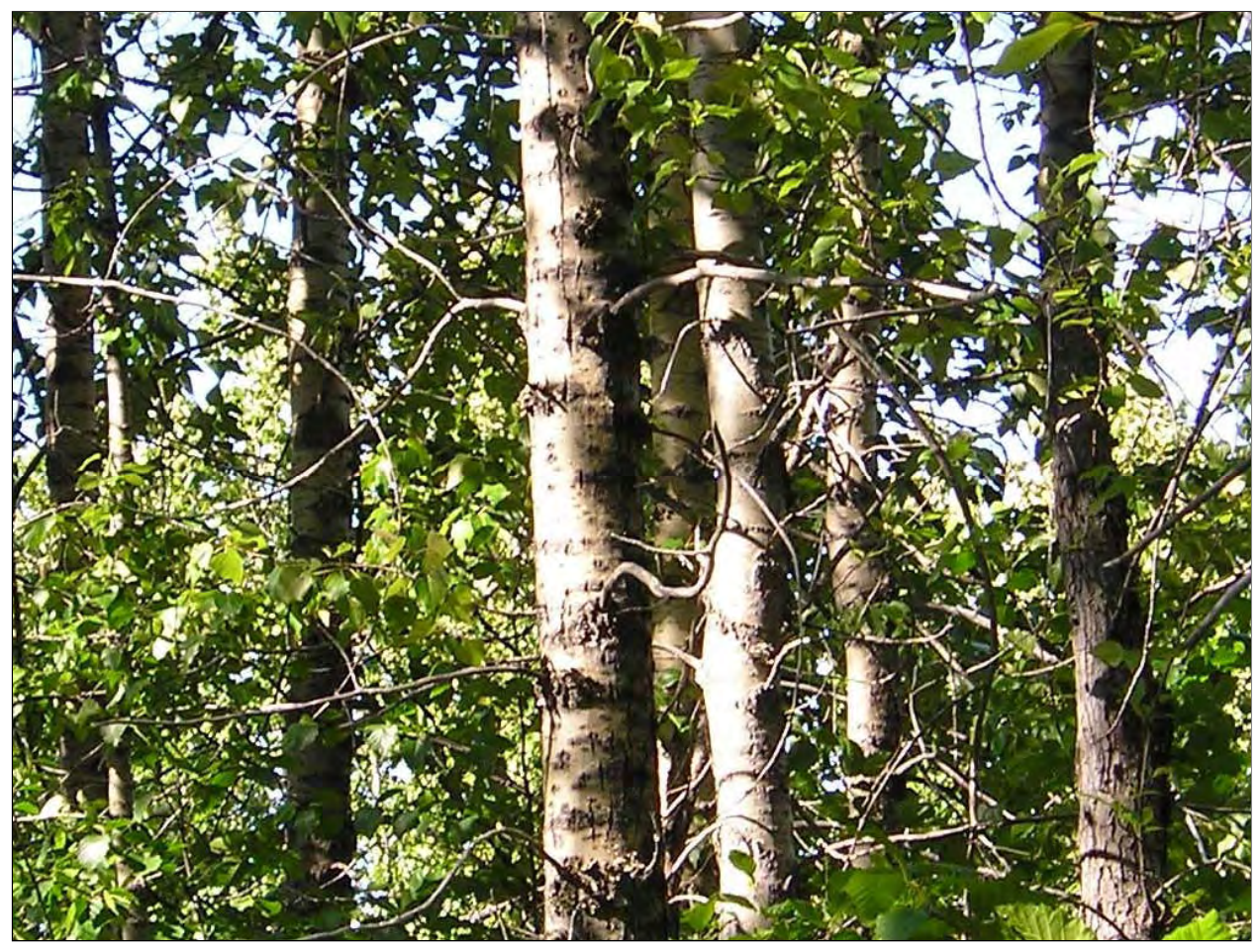

Poplar, cottonwood, alder, and willow are broadleaf trees and shrubs that survived the late Miocene and Pliocene cooling events in Alaska. All of these plants survive today in the boreal forest of Alaska except cottonwood, which grows in the coastal forest.

Photo by Dr. Thomas Ager, USGS. 


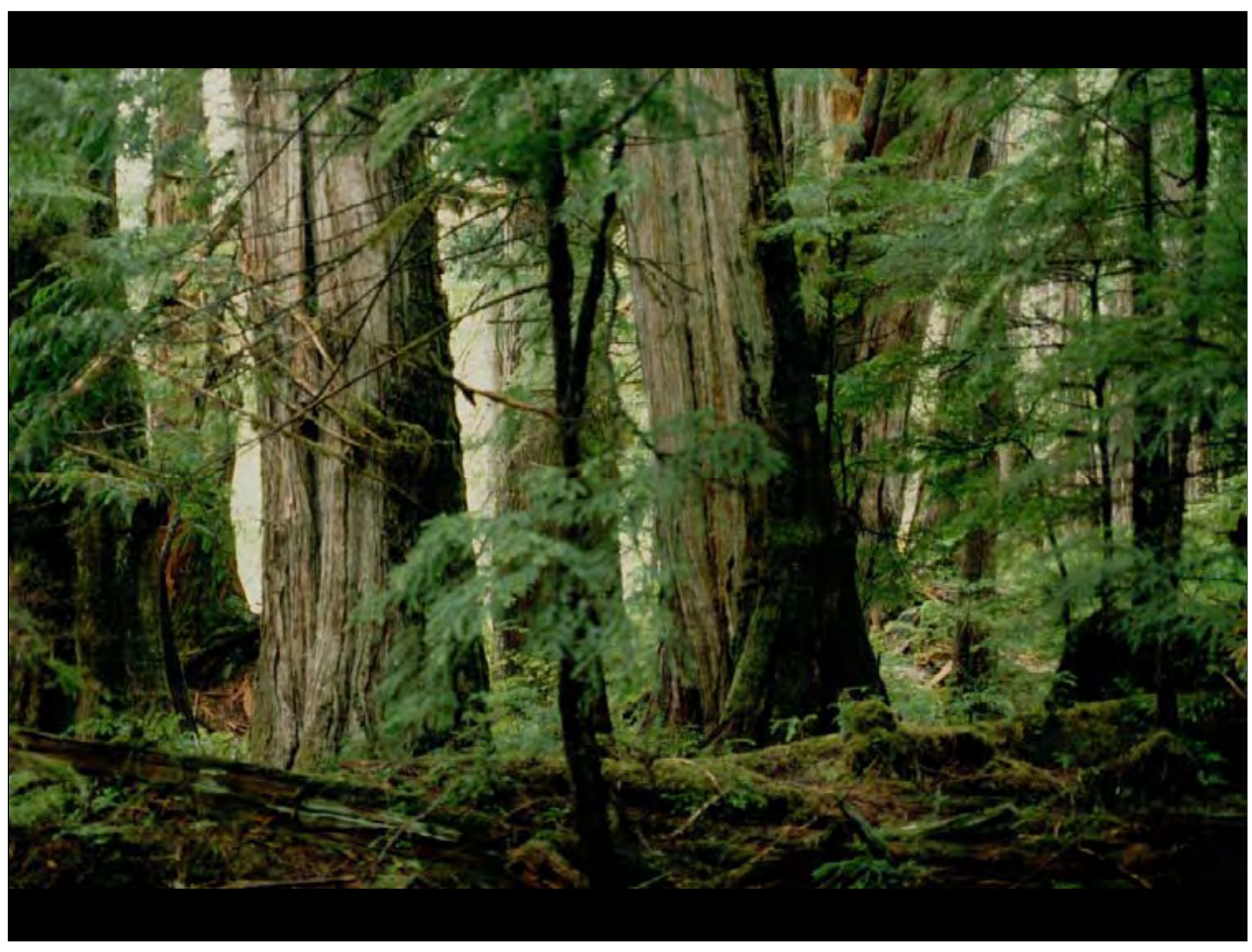

Late Miocene forests of interior and southern Alaska included many tree types that now grow along the Pacific Northwest coast. This photograph shows a stand of mature western hemlock trees that grow in southeastern and parts of south-central Alaska today. Western hemlock and other coastal trees once grew in interior Alaska, far inland from the coast. This implies that the climate of interior Alaska was warmer and wetter than it is today, and winters were far less severe. During the latest Miocene and Pliocene, the rise of the Alaska Range resulted in the development of a more continental climate in interior Alaska. This gradually eliminated conifer types from the interior that now grow along the southern or southeastern coasts of Alaska (for example, hemlock, pine, and cedar).

Photo by Dr. Thomas Ager, USGS. 


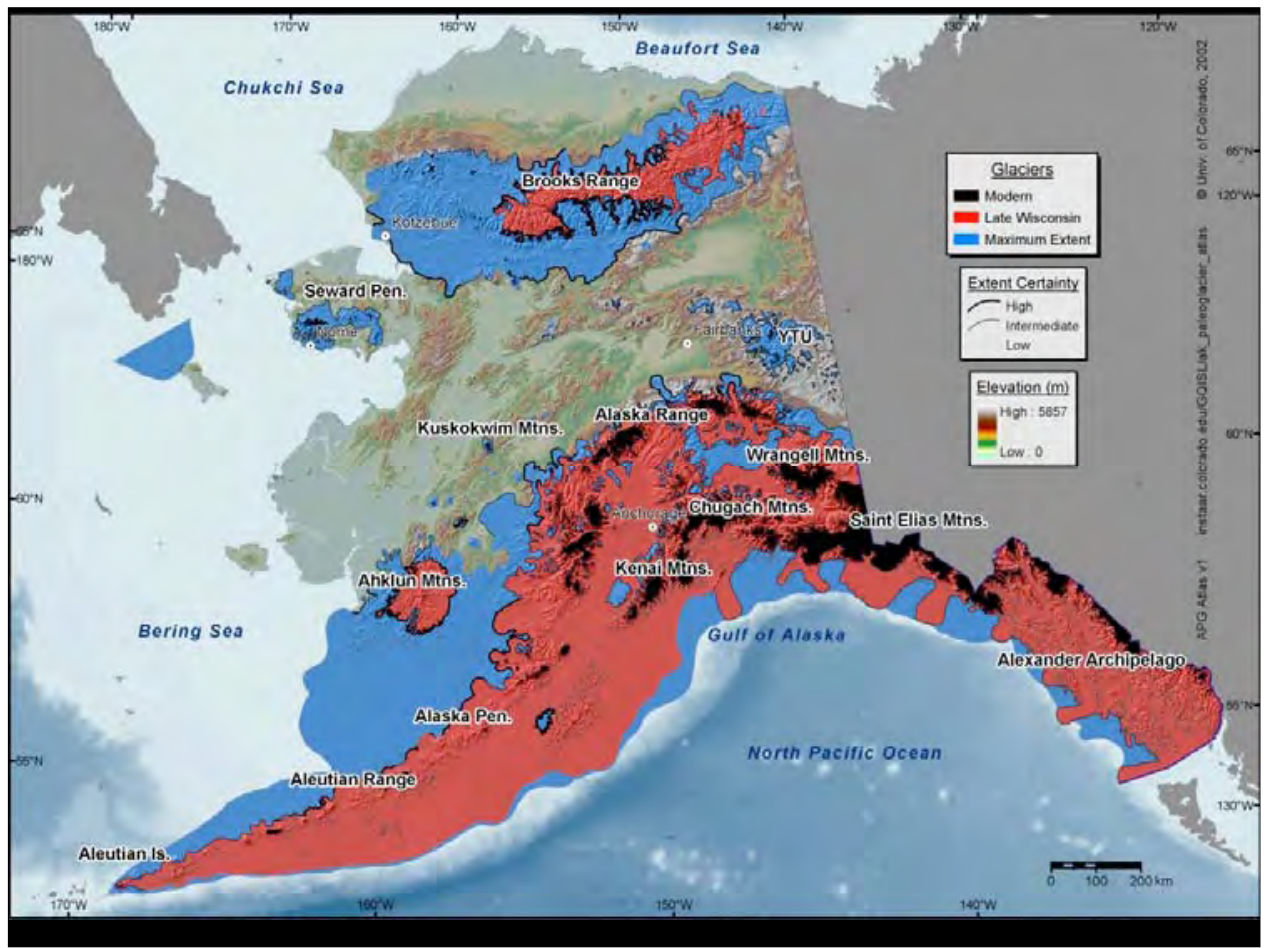

Map of Pleistocene glacial extent in Alaska. Blue represents the maximum glacial limits known in Alaska and may represent late Pliocene and (or) early Pleistocene glaciations. Red approximates the glacial limits during the late Wisconsin glaciation, ca. 25,000 -10,000 yr B.P. Black areas depict present-day glaciers and icefields, which cover about 4 percent of the present land area of Alaska. During the late Wisconsin, glaciers covered about 30 percent of Alaska. During the maximum glaciation(s) of Alaska, glaciers covered about 50 percent of Alaska.

Map courtesy of Dr. William Manley (Institute of Arctic and Alpine Research, University of Colorado) and Dr. Darrell Kaufman (University of Northern Arizona). 


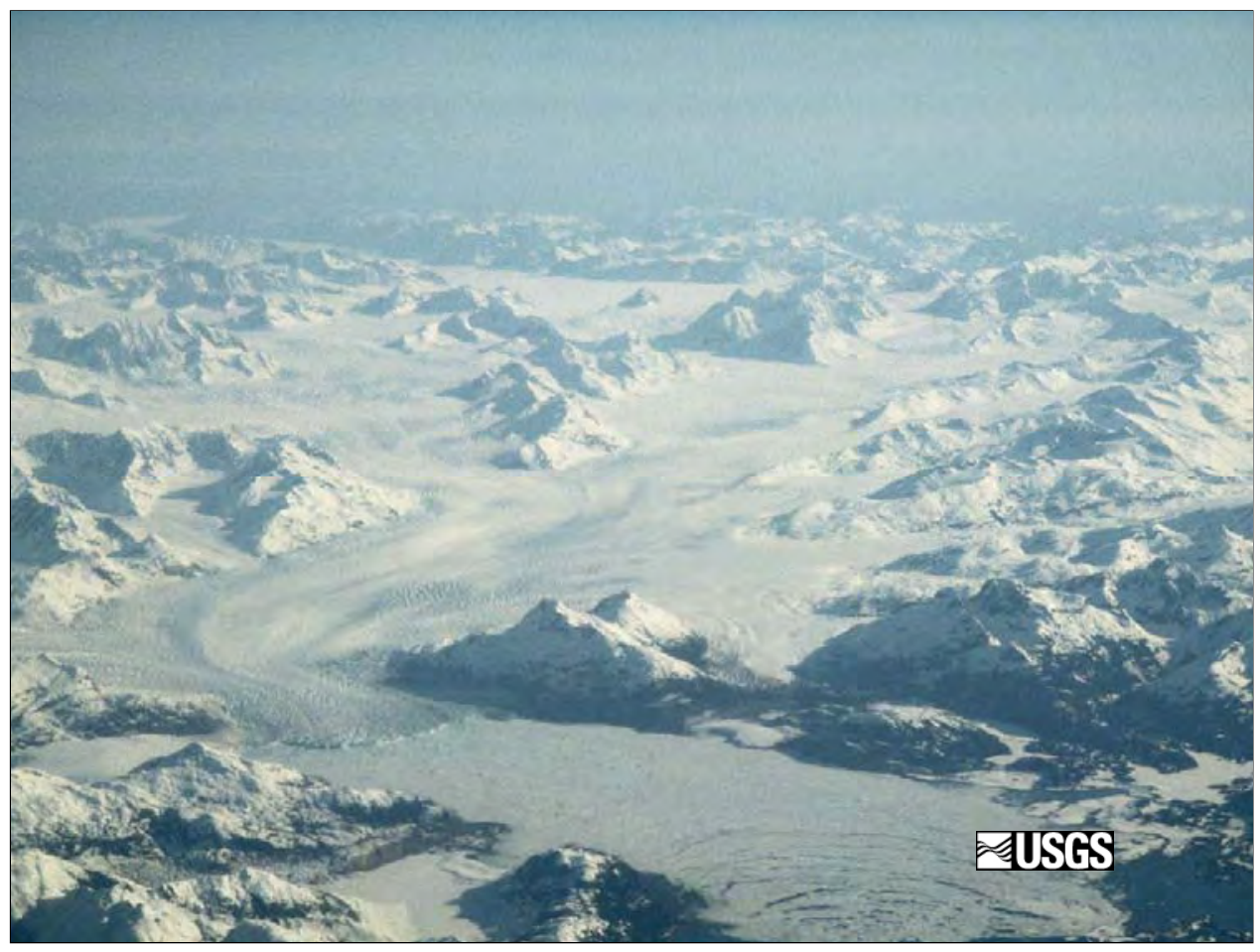

The present-day icefields in the mountains adjacent to the Gulf of Alaska represent the largest area of glaciers in the northern hemisphere outside of Greenland. Yet this impressive glacial landscape represents just a small remnant of icefields that existed in past glaciations. During the late Wisconsin glacial interval, ice covered about 30 percent of Alaska (plus vast areas of the continental shelf in the Gulf of Alaska). Little is known of the details of glacial history in the Gulf of Alaska region, and relatively little research has focused on it.

Photo by Dr. Thomas Ager, USGS. 


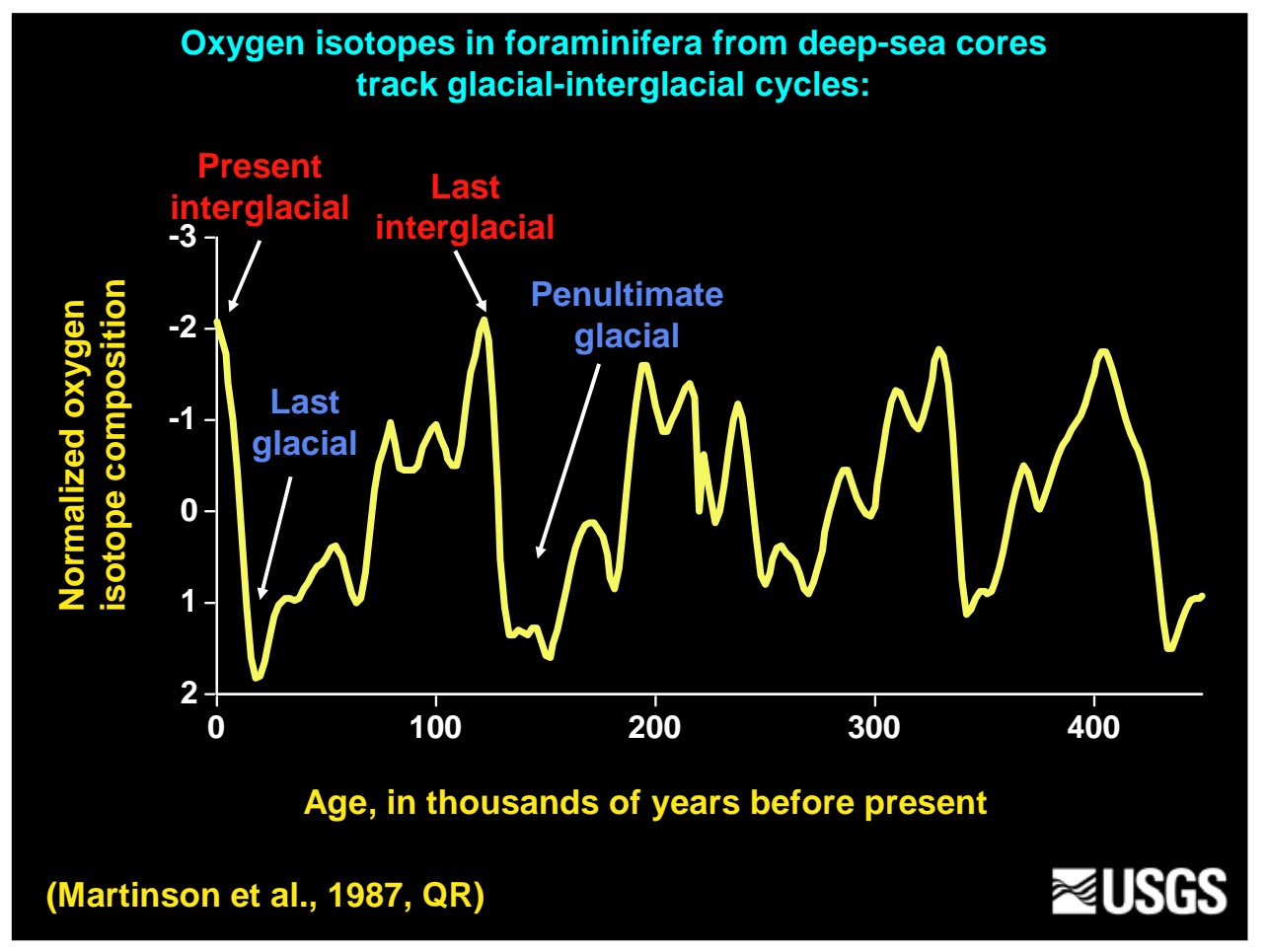

Now we will examine the more recent history of climate changes in Alaska, and examine the effects of major cooling and warming events of the past ca. 2.5 million years. Oxygen isotope curves derived from foraminifera from deep ocean cores can be interpreted to reflect changes in sea water temperatures and global ice volumes over hundreds of thousands to millions of years. This curve shows several interglacial or interstadial warm events separated by much longer intervals of cold, dry glacial climates. The marine oxygen isotope curves suggest that about 50 glacial-interglacial cycles have occurred during the past ca. 2.5 million years. The most climatically extreme glacialinterglacial cycles have occurred during the past ca. 950,000 years. In Alaska and northwestern Canada, paleobotanical evidence has been documented from about eight interglacial events that occurred during the past 2.2 million years. That record is incomplete, but the pollen evidence from these 8 interglacials shows a remarkably consistent history of spruce-dominated boreal forest during interglacial times. This contrasts markedly with early Pliocene forests of Alaska that contained more conifer types, including hemlock, fir, spruce, larch, and pine. Cold climate intervals vastly reduced forest vegetation, and tundra dominated the landscapes for most of the past 2.5 million years.

Reference: Martinson, D.G., Pisias, N.G., Hayes, J.D., Imbrie, J., Moore, T.C., Jr., and Shackleton, N.J.,1987. Age dating and the orbital theory of ice ages: Development of a high-resolution 0 to 300,000 year chronostratigraphy: Quaternary Research, v. 27, p. 1-29. 


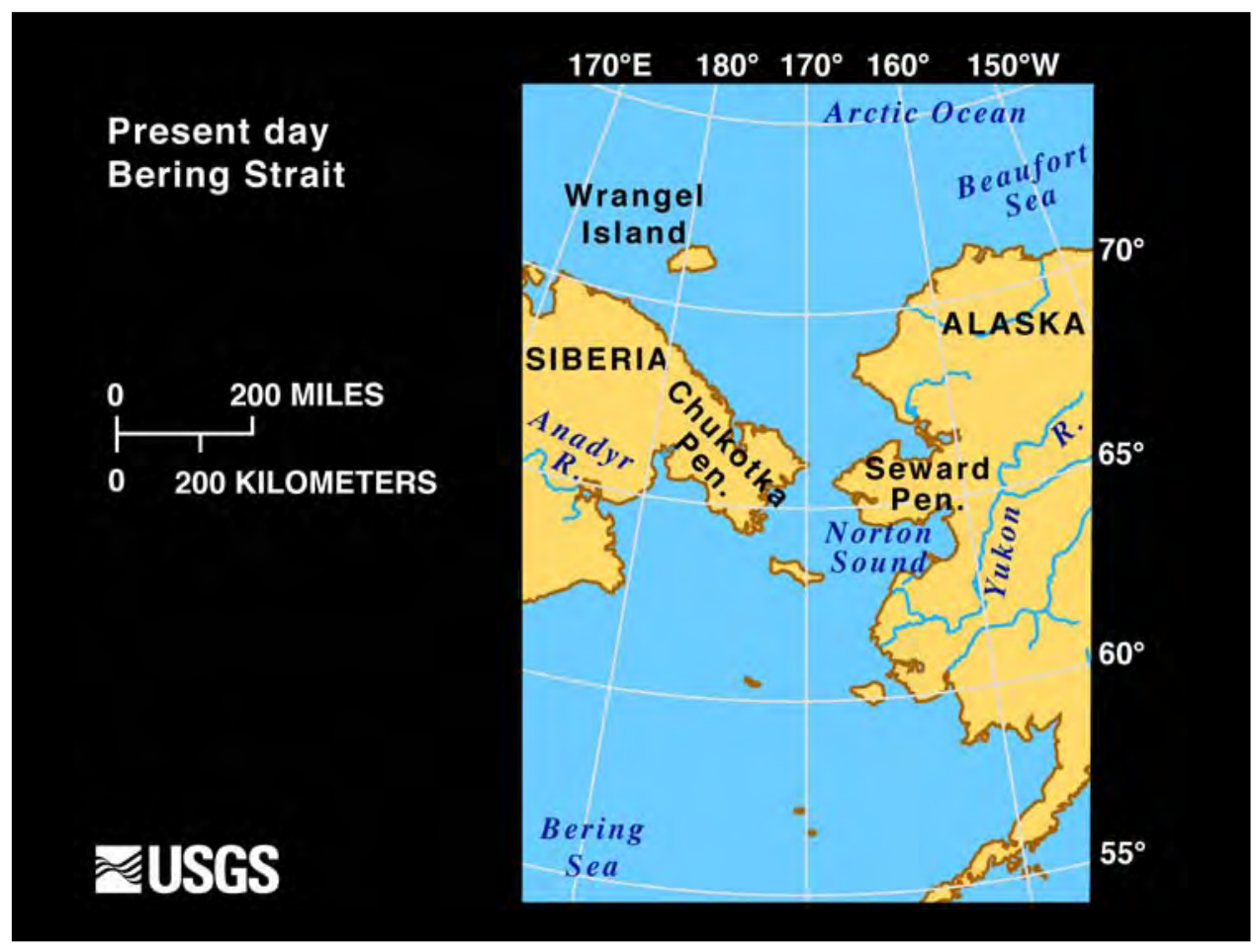

Map of present-day western Alaska, the Bering Sea, the Arctic Ocean, and eastern Siberia. During glacial times, so much of the Earth's water was stored on land as glacial ice and snow that sea level dropped dramatically. During the most recent glaciation (about 27,000 -11,500 years ago), sea level dropped about 125 meters below present sea level. 




Lower sea levels during glacial times exposed continental shelves in many parts of the world. When the lowering of global sea level reached its maximum (100 to $125 \mathrm{~m}$ below present sea level), a vast area of shallow sea floor was exposed between western Alaska and Siberia (as well as large areas north of Siberia). This large land connection between northwestern North America and northeastern Asia (the Bering land bridge) has served as an important route that allowed animals and plants to spread between North America and Eurasia. During major glaciations, Alaska was isolated from the rest of North America by the Cordilleran and Laurentide ice sheets, and became an eastern extension of northeastern Asia. Glacial climates of the Bering land bridge and adjacent land masses were dry and cold, but summers were warm enough to support grassy tundra or tundra/steppe vegetation. 


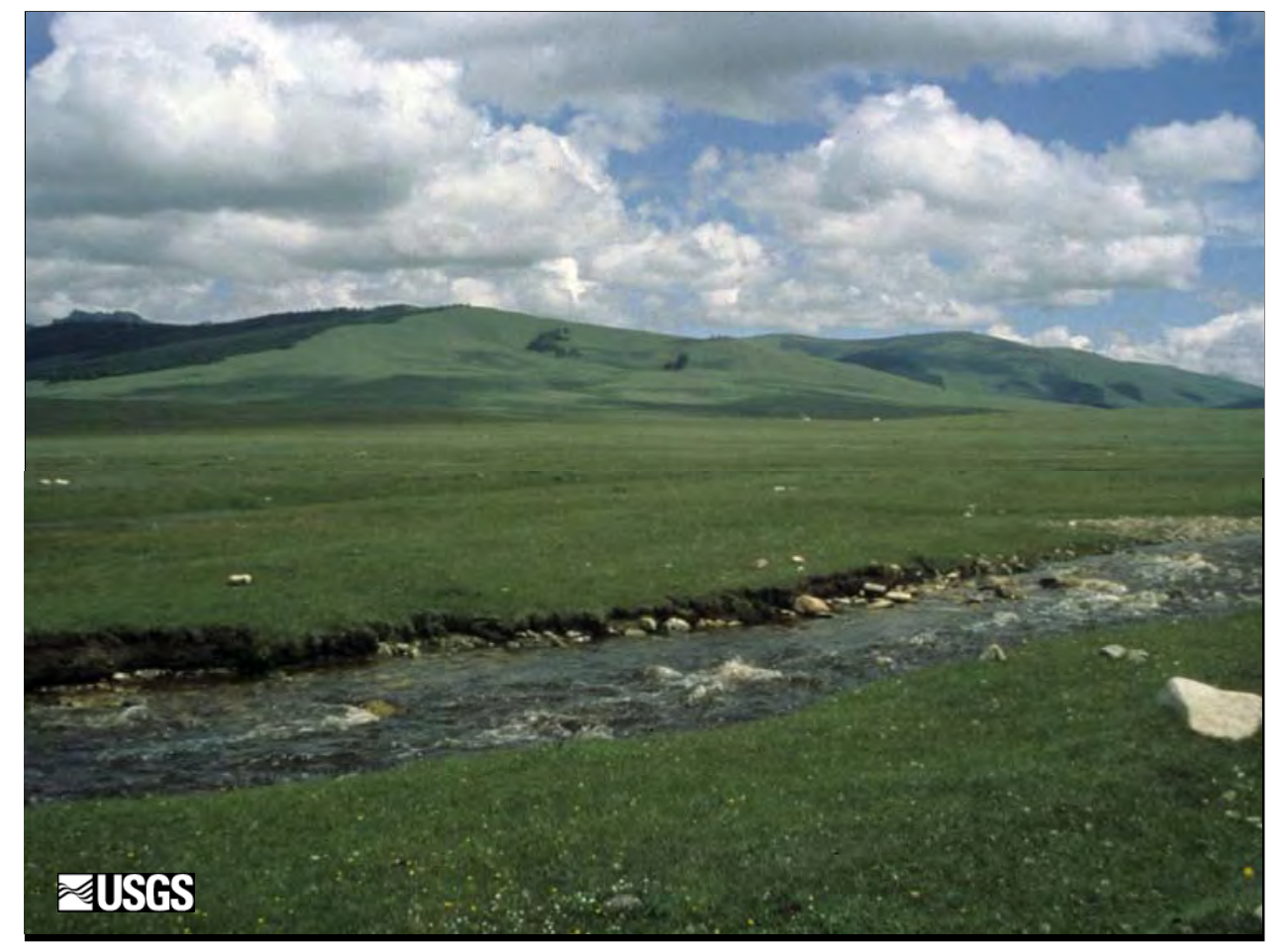

Do modern analogs exist for the past full-glacial vegetation of the Bering land bridge and interior Alaska? No exact modern analog may exist, but there may be near analogs such as this Kobresia-herb vegetation in northern Mongolia. Other near-analog vegetation exists today on Wrangel Island north of northern Siberia. Fossil pollen and plant macrofossil evidence from Alaska and Yukon Territory indicate that forest vegetation was essentially eliminated from the landscape. However, genetic studies of spruce populations in western North America suggest that some spruce trees probably survived in Alaska or Yukon Territory during the last major glacial interval. Small populations of spruce trees may have survived in sheltered valleys, but so far, no convincing fossil evidence has been found to show where such trees may have survived.

Photo by Dr. Steve Young, Center for Northern Studies. 


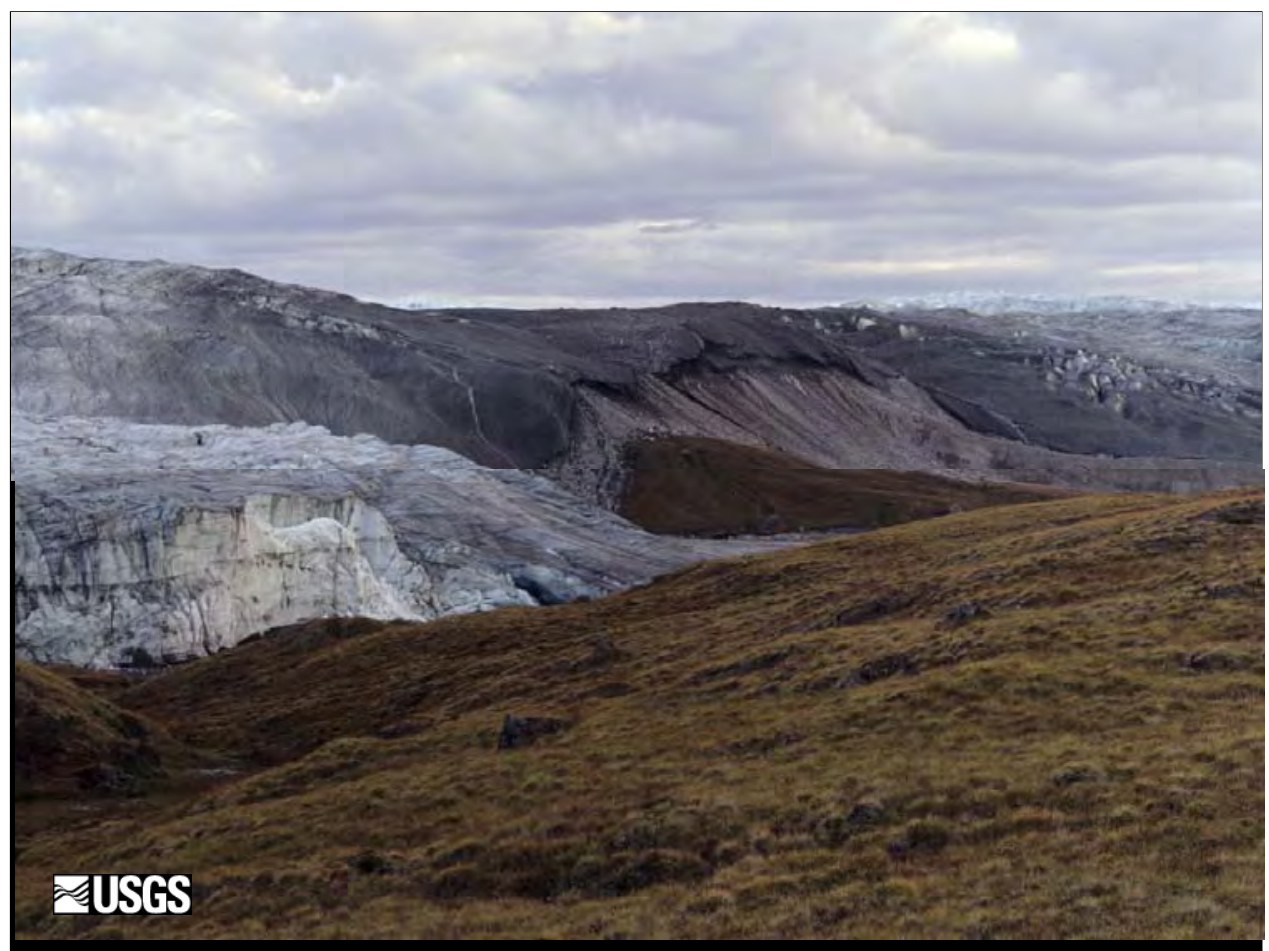

Grass-sedge-herb tundra adjacent to the Greenland ice sheet may be another reasonable analog for full-glacial vegetation on the Bering land bridge and interior Alaska and Yukon.

Photo by Dr. Todd Hinkley, USGS. 


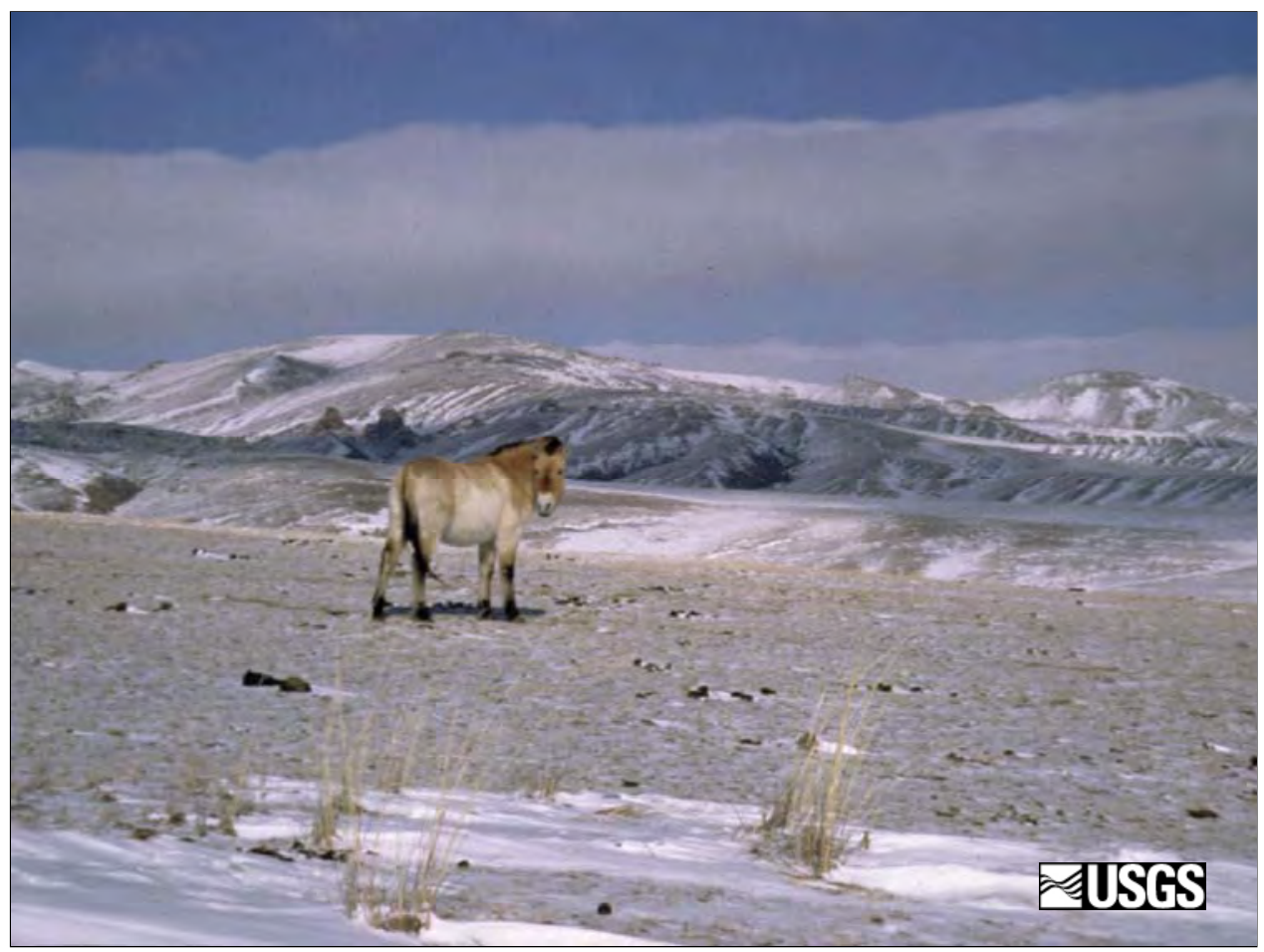

This late winter photograph (taken in Mongolia) of a Przewalski's horse in Mongolia probably approximates the conditions that prevailed during full glacial time on the Bering land bridge and in interior Alaska: thin snow cover and sparse, grassy vegetation.

Photo by Dr. Richard Reading, Wildlife Conservation Biologist, Denver Zoo. 


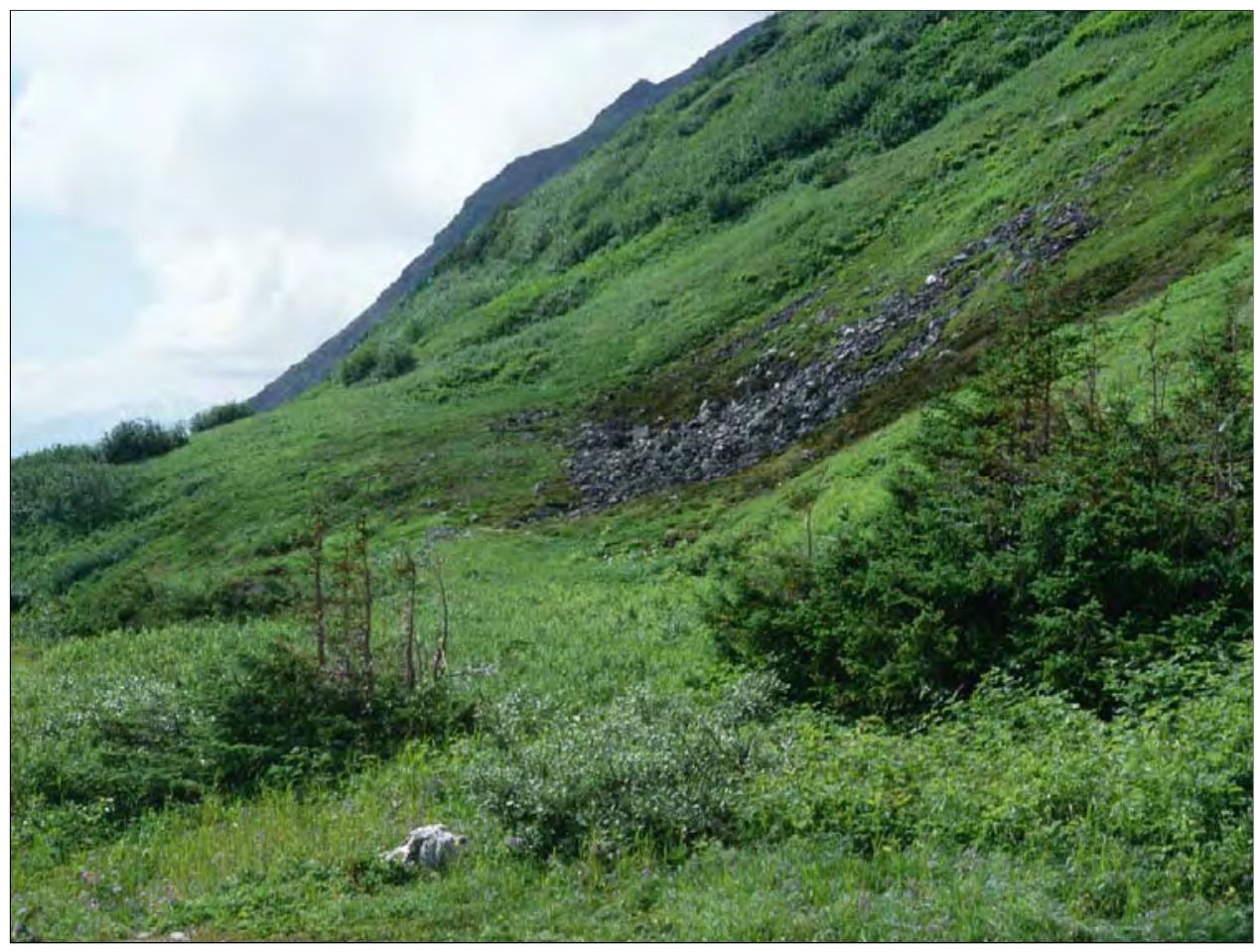

Fossil plant and pollen assemblages from Alaska and Yukon Territory suggest that interior regions were treeless, or nearly so. Genetic evidence from modern spruce populations in Alaska suggest that boreal spruce may have survived in unglaciated parts of eastern Alaska and Yukon during the late Wisconsin. If so, they were probably scattered, small populations that may have been stunted, low-growing trees such as these spruce near the altitudinal limits of tree growth in the coast mountains of southeastern Alaska.

Photo by Dr. Thomas Ager, USGS. 


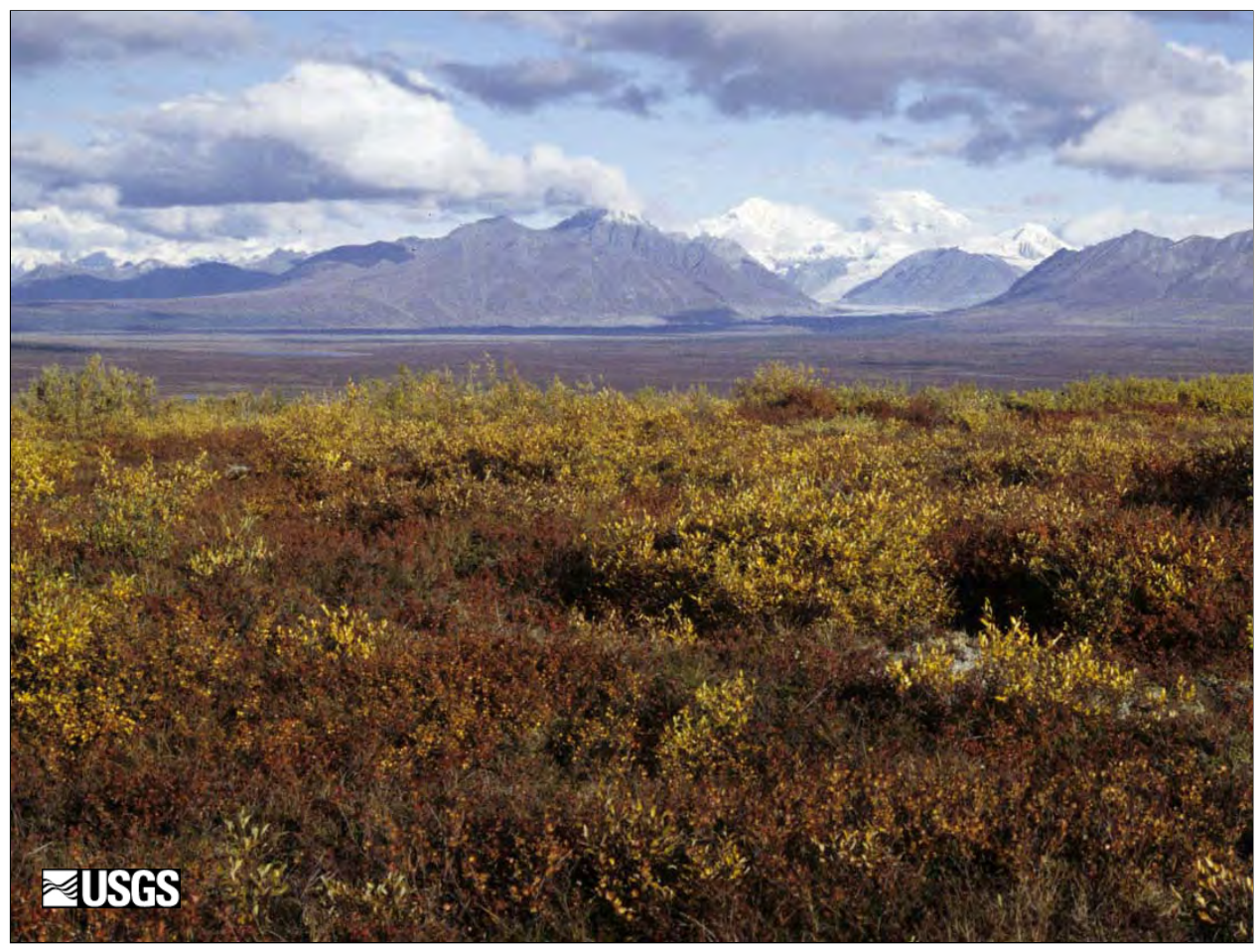

Soon after deglaciation, much of the herb-dominated tundra vegetation was rapidly displaced by shrub-herb tundra composed largely of dwarf birch, willow, blueberry, labrador tea, crowberry, along with cottongrass and other sedges, grasses, and tundra herbs. This type of vegetation was well established in Alaska by about 15,500 yr B.P.

Photo by Dr. Thomas Ager, USGS. 


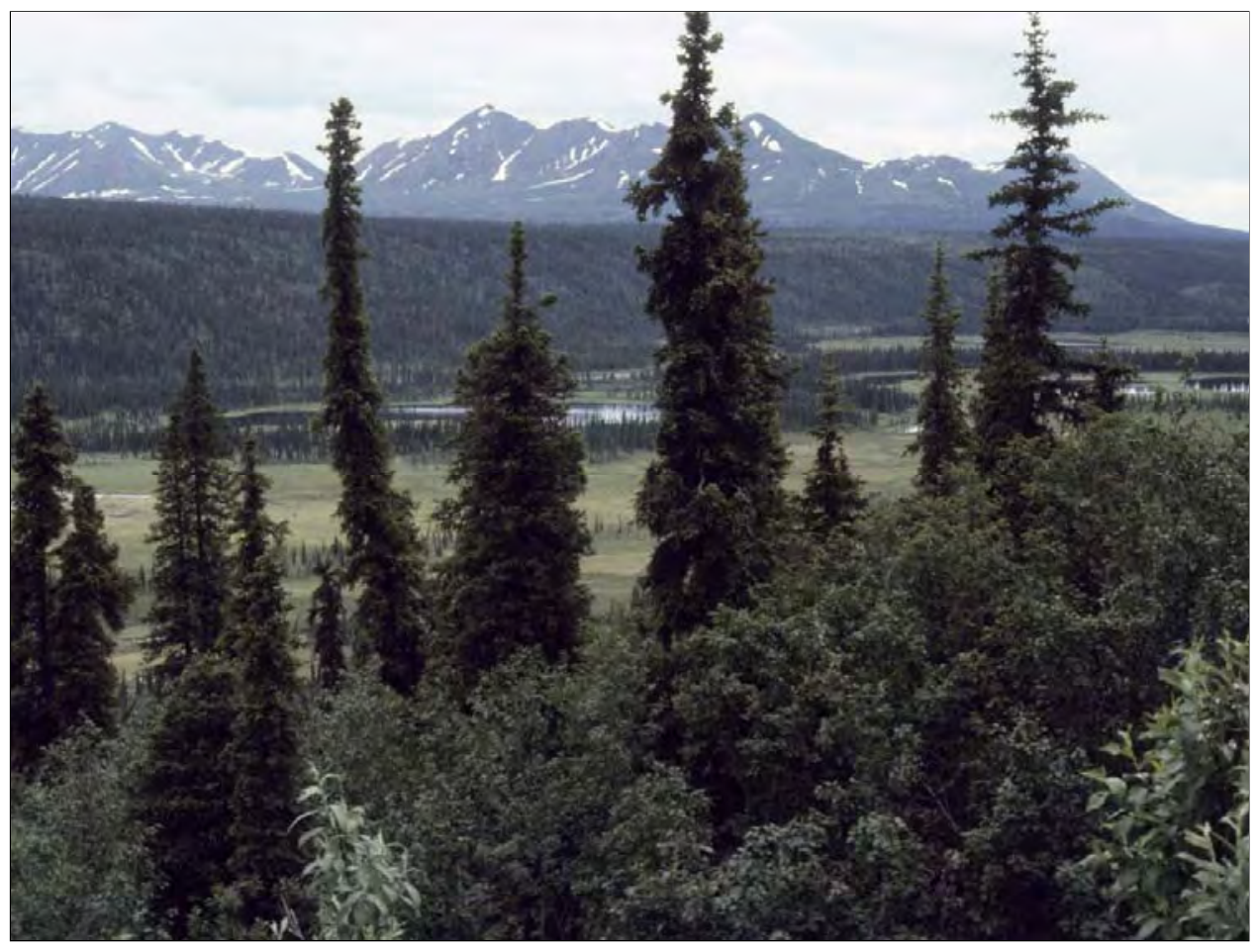

By about 2.2 million years ago, interglacial vegetation in interior and inland south-central Alaska was composed of boreal forest trees and shrubs that exist in these regions today, during the present Holocene interglacial. Major trees and shrubs common in interglacials include spruce, larch, birch, poplar (and probably aspen), alder, willow, bayberry, and heaths (blueberry, huckleberry, cranberry, Labrador tea, and crowberry). During glaciations, boreal forest vegetation was either eliminated from interior Alaska by cold, dry temperatures, or their populations were greatly reduced and restricted in their distribution.

In south-central and other mountainous areas of Alaska, forest vegetation was eliminated by the expansion of glaciers and glacial lakes in lowlands during late Pliocene-Pleistocene ice ages.

Photo by Dr. Thomas Ager, USGS. 


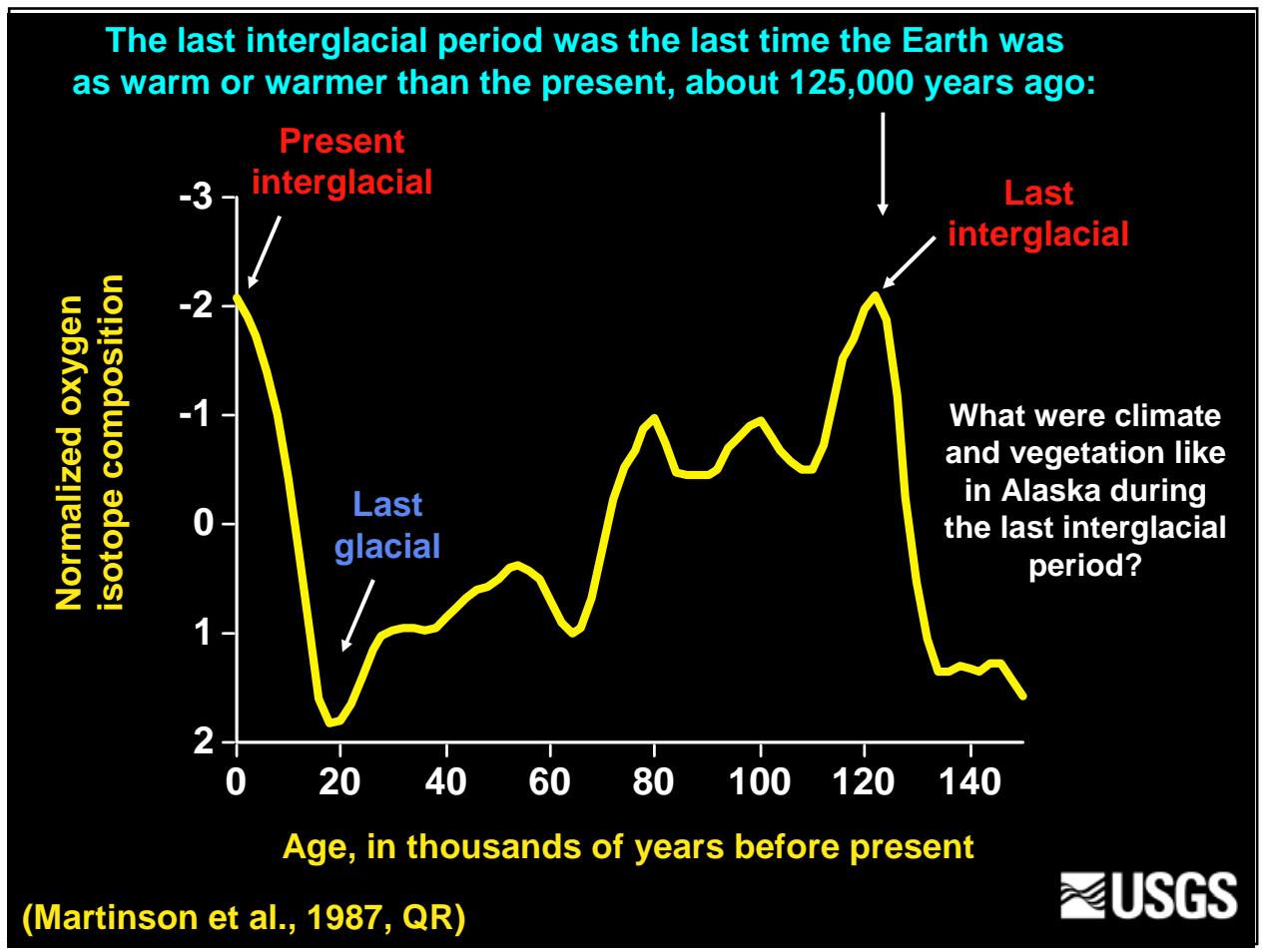

Oxygen-isotope curve derived from analysis of foraminifera in deep ocean cores provides a sea-water temperature history for the past ca. 150,000 years. It shows that the last interglacial lasted about 20,000 years, and the present interglacial has been underway for 10,000 years. For 120,000 of the past 150,000 years, glacial or interstadial climates have dominated. Interstadials are intermediate between cold, full glacial climates and relatively warm interglacial climates. In Alaska, forest vegetation was widespread only during interglacials and was greatly reduced or possibly eliminated during glacial times.

Reference: Martinson, D.G., Pisias, N.G., Hayes, J.D., Imbrie, J., Moore, T.C., Jr., and Shackleton, N.J., 1987. Age dating and the orbital theory of ice ages: Development of a high-resolution 0 to 300,000-year chronostratigraphy: Quaternary Research, v. 27, p. 1-29.

Figure courtesy of Dr. Dan Muhs, USGS. 


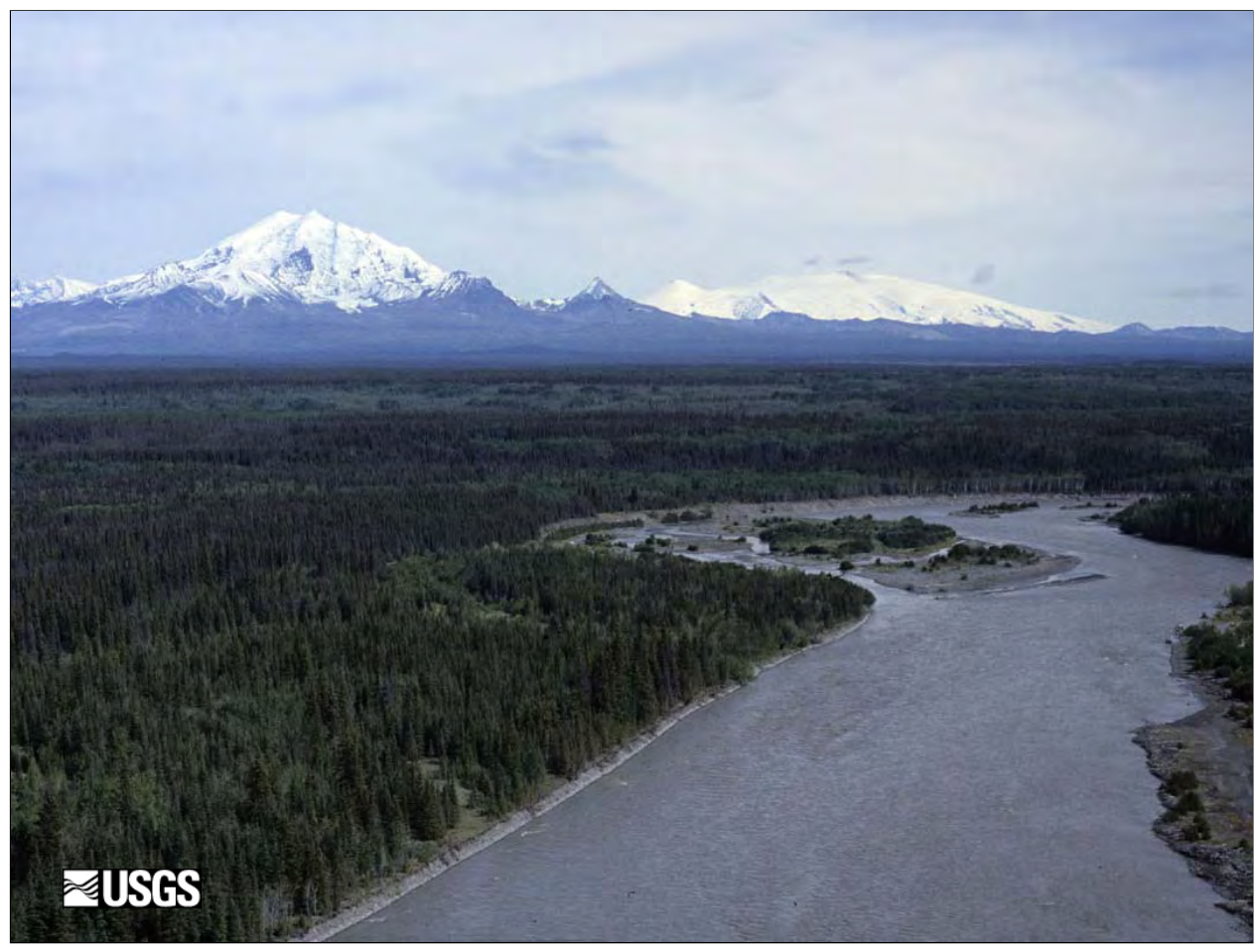

Boreal forest composed of white spruce, black spruce, alder, willow, balsam poplar, and aspen cover much of interior and inland southcentral Alaska today. It spread across interior and much of western Alaska between about 10,000 - 6,000 years ago. This photograph was taken in Copper River basin, with Wrangell Mountains in background.

Photo by Dr. Thomas Ager, USGS. 


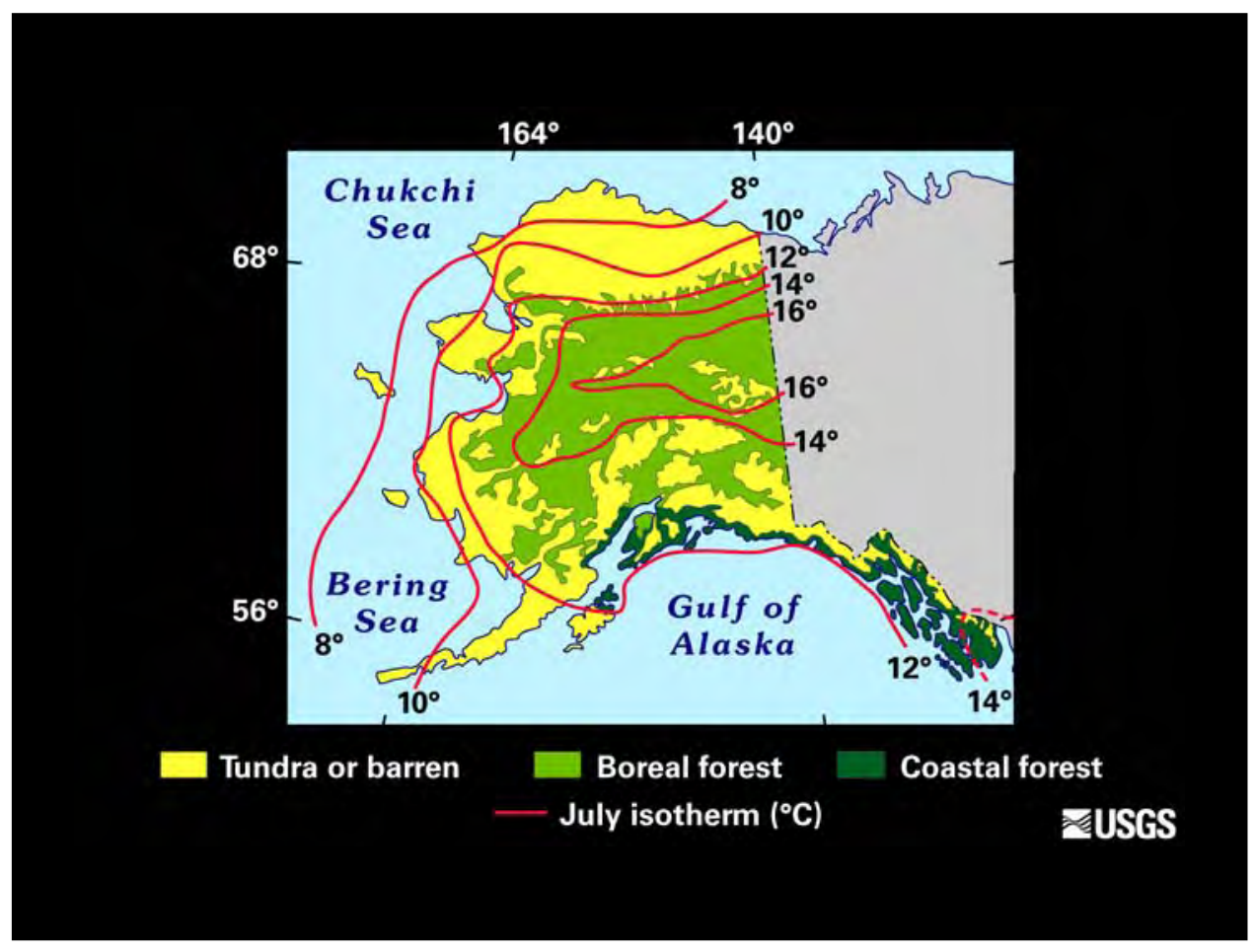

Vegetation map of Alaska today (after Viereck and Little, 1972), to bring our focus on the Cook Inlet area of south-central Alaska, where alpine and shrub tundra, boreal forest, and coast forest vegetation grow today in close proximity and in fact overlap in some areas. Cook Inlet is located northwest of the Gulf of Alaska as shown here.

Reference: Viereck, L.A., and Little, E.L., Jr., 1972. Alaska trees and shrubs: Washington, D.C., USDA Forest Service Agriculture Handbook no. 410,265 p. 


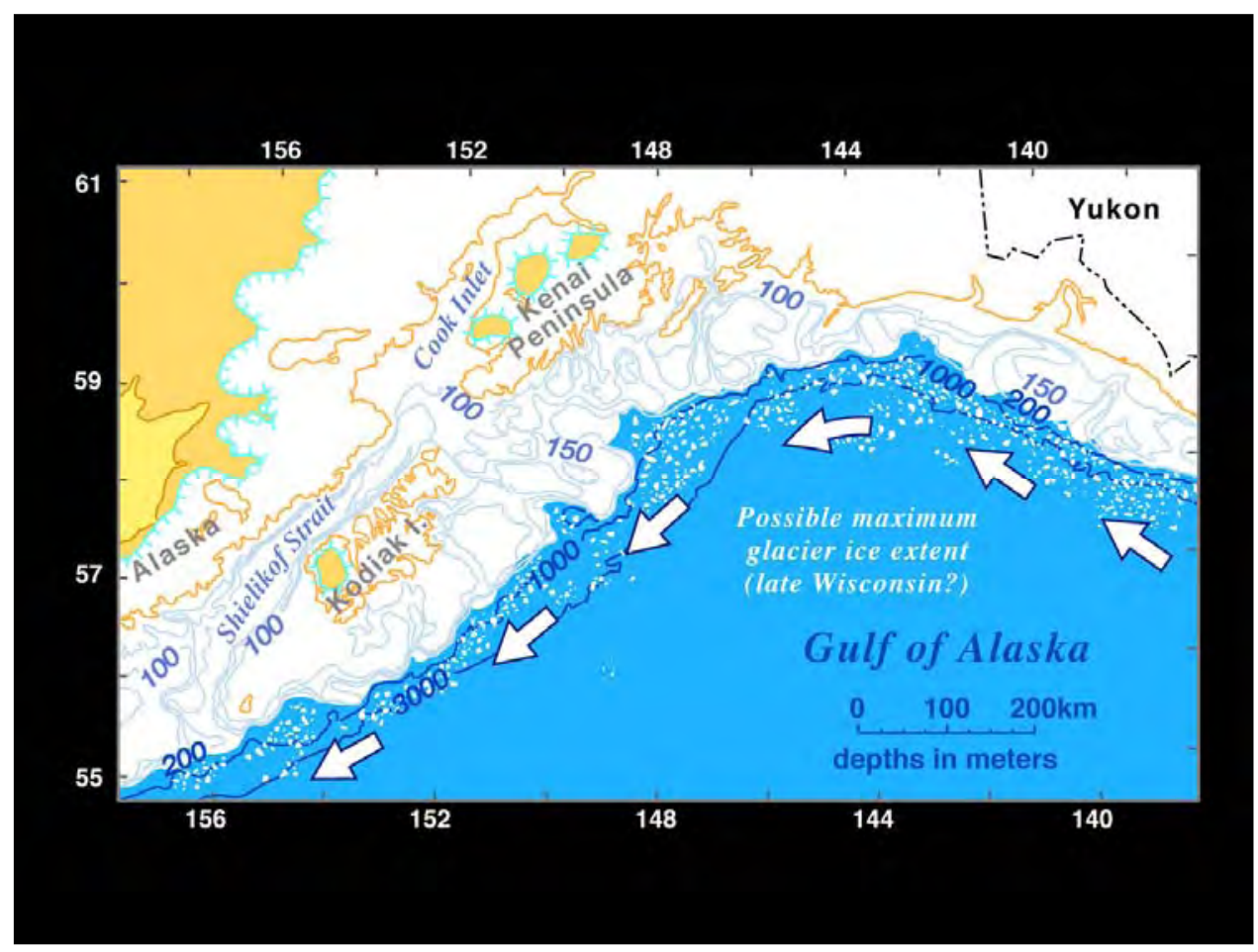

During maximum glacial events of the Pleistocene, it is likely that glaciers expanded all the way to edge of the continental shelf, leaving few areas of exposed land to act as refugia for plants and animals.

The extent of glacial ice in south-central Alaska during the most recent major glaciation, the late Wisconsin glacial interval, is not well understood, however. It may have been less extensive than shown here. Areas of south-central Alaska that escaped total burial by glacial ice supported mostly alpine and graminoid-herb tundra vegetation. Such areas included part of southwestern Kodiak Island and parts of the western Kenai Peninsula. 


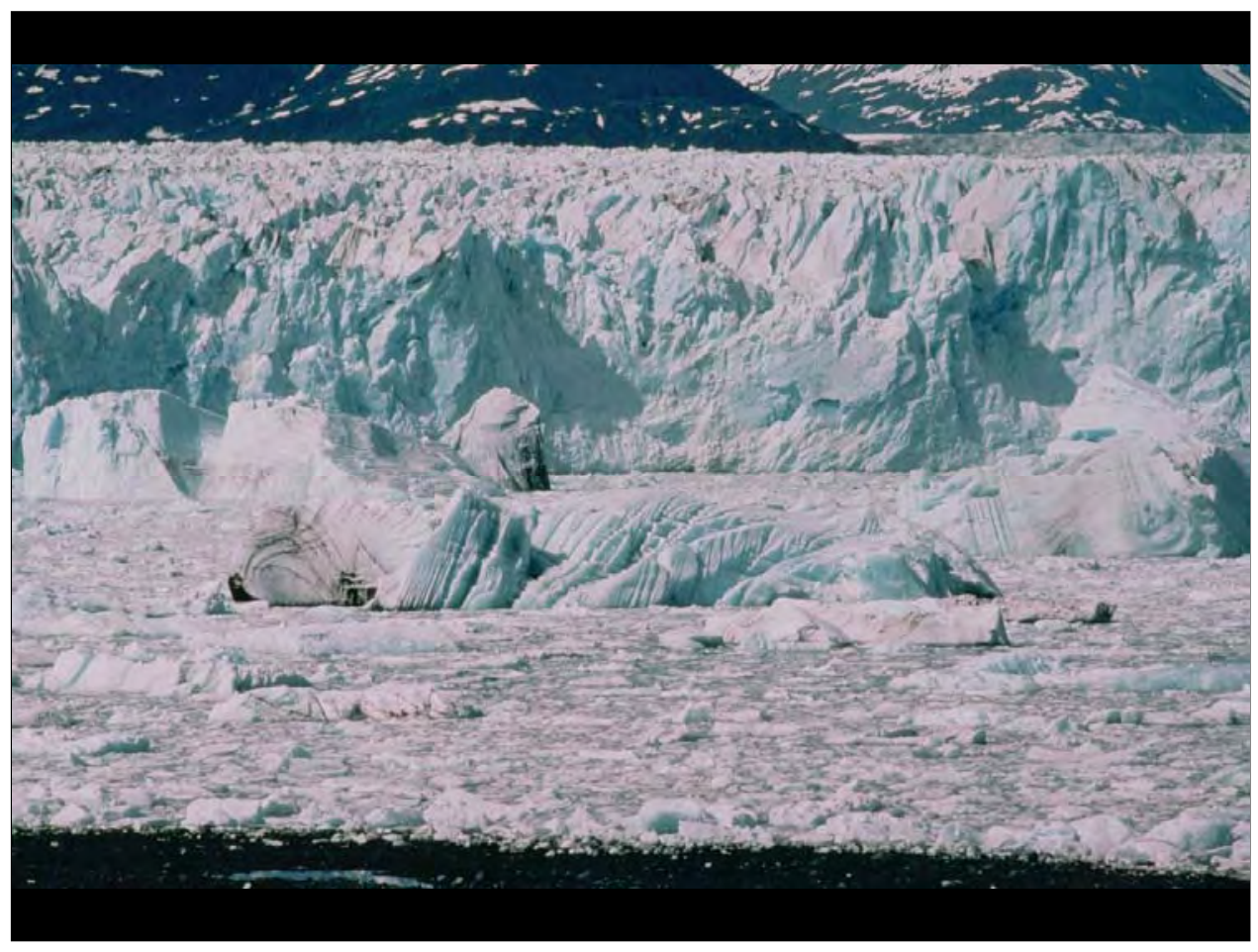

Glaciers covered most of the Cook Inlet region during the last glaciation, but glacial retreat began about 18,000 years ago. Deglaciation was interrupted by at least three brief readvances of glaciers, with each advance less extensive than its predecessors.

Photo by Dr. Austin Post, USGS. 


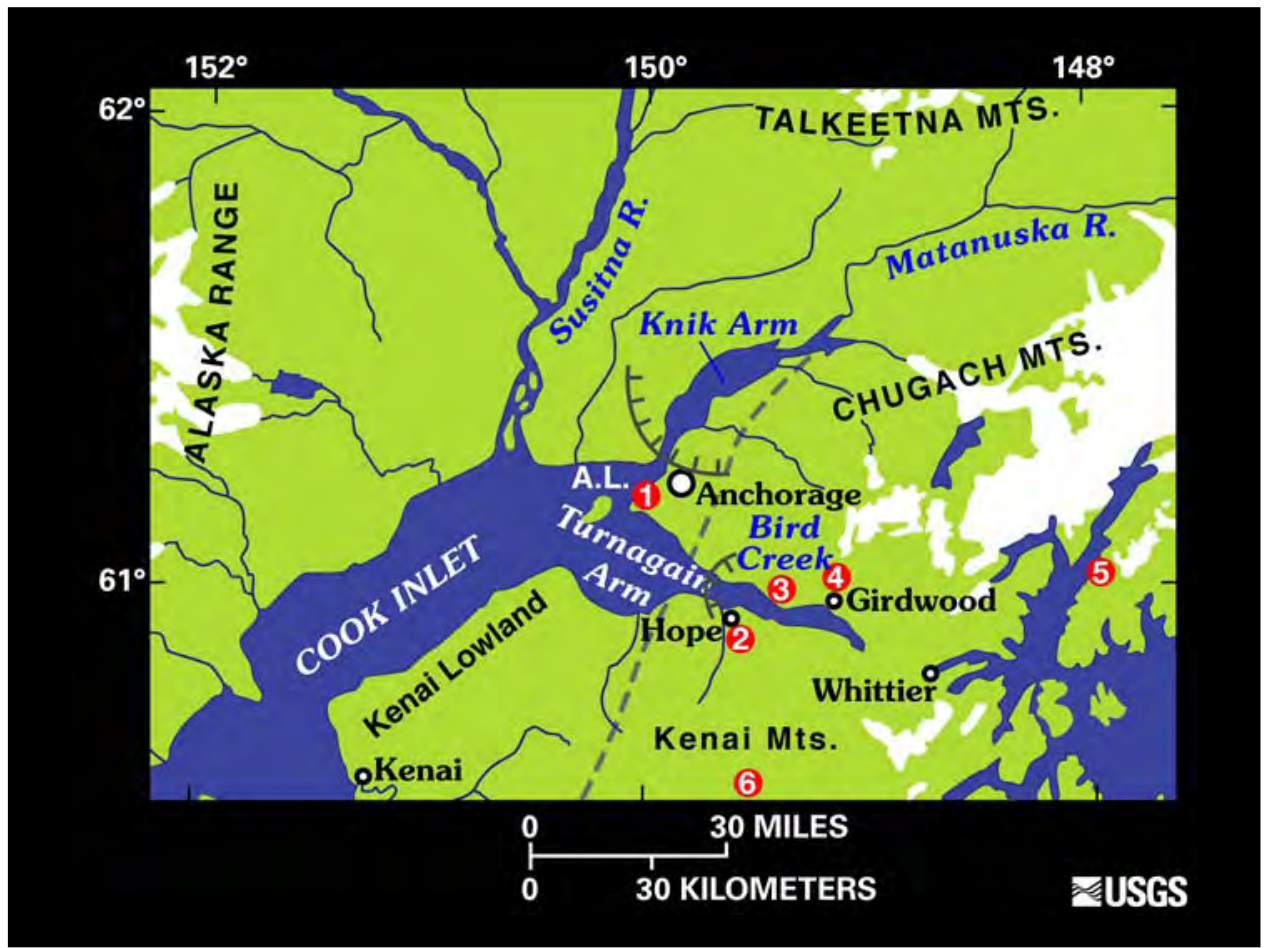

Map of upper Cook Inlet region today, with hatchured semicircles showing maximum terminal positions of the last glacial advance in Knik and Turnagain Arms (Elmendorf Stade, ca. 16,000-14,000 yr B.P.). Pollen records from the Anchorage lowland (A.L., site 1) and eastern Turnagain Arm (Girdwood, site 4) record vegetation changes in the region since about $14,500 \mathrm{yr}$ B.P.

The history of vegetation development in the Anchorage lowland (site 1) reflects the drier, colder climates associated with areas in the precipitation shadows formed by the Chugach and Kenai Mountains. 


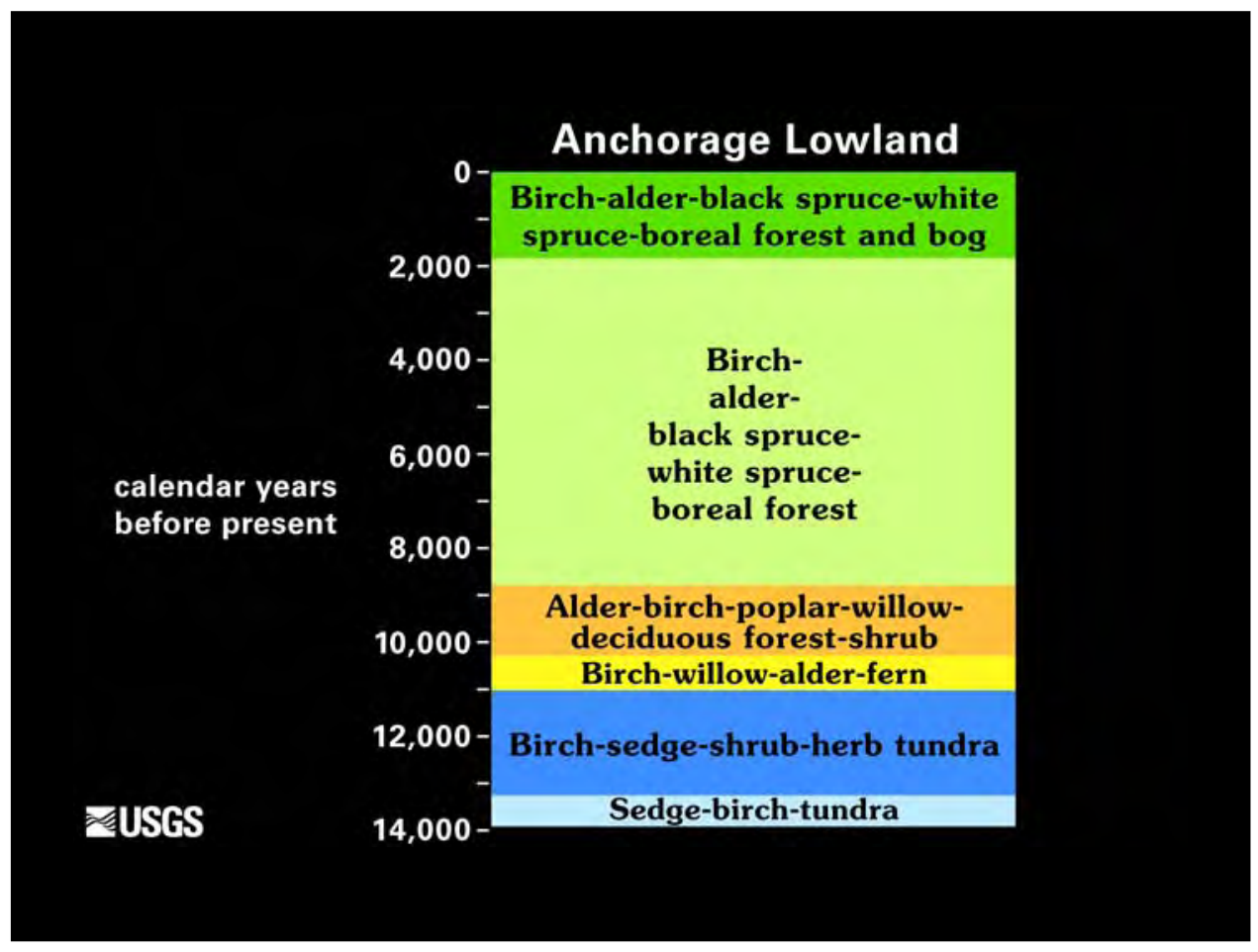

In the Anchorage lowland, deglaciation and marine inundation were followed by isostatic rebound of the lowland to a position above sea level by about 14,000 yr B.P. Sedge-birch tundra colonized the lowland, followed quickly by birch-sedge-shrub-herb tundra, then birchwillow-alder-fern tundra and shrubland. Poplar trees and willows colonized by about 10,000 yr B.P., and boreal spruce colonized the area by about $8,800 \mathrm{yr}$ B.P.

Chart based on data from Dr. Thomas Ager, USGS. 


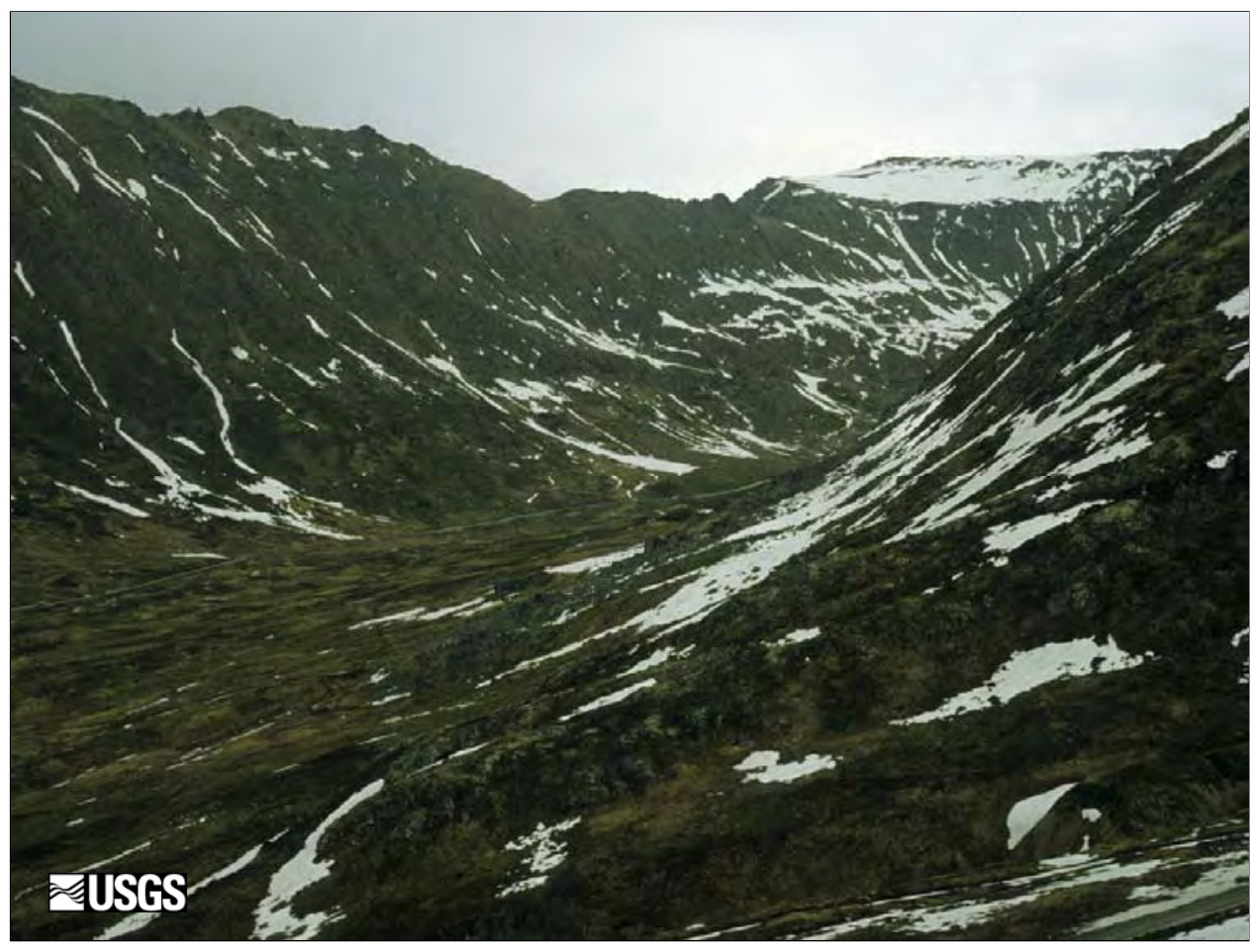

Alpine tundra (early summer) in the southwestern Talkeetna Mountains of south-central Alaska provides a likely modern analog for the tundra vegetation that colonized much of south-central Alaska during and immediately following deglaciation. Tundra vegetation became shrubbier over time, as herbaceous plants were partly displaced by willow and heath species.

Photo by Dr. Thomas Ager, USGS. 


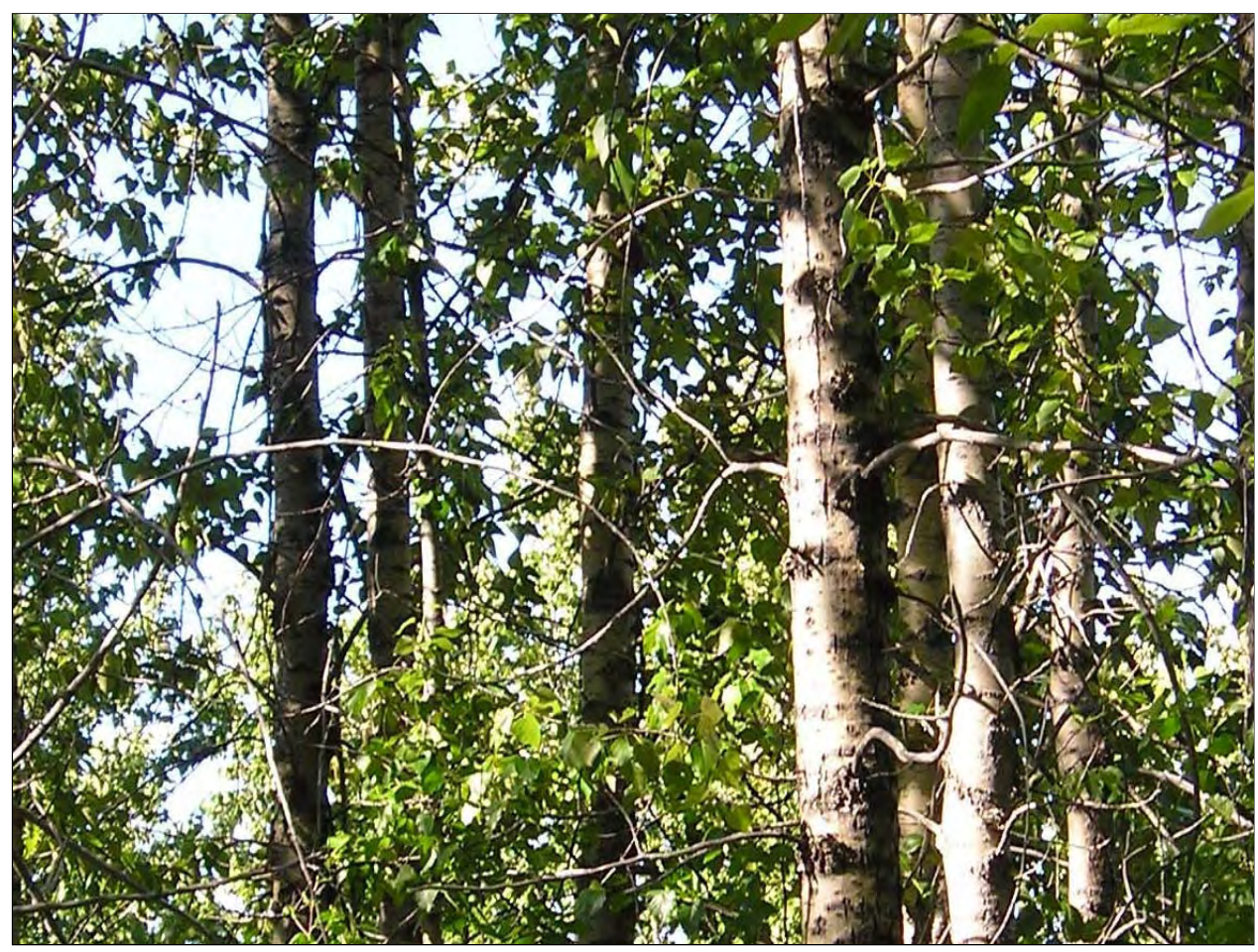

The first trees to colonize Cook Inlet were members of the poplar genus (Populus): balsam poplar (Populus balsamifera), and perhaps aspen (Populus tremuloides) and cottonwood (Populus trichocarpa). The history of these tree species is incomplete, because the pollen they produce is thin-walled and is often not preserved in the fossil record.

Photo by Dr. Thomas Ager, USGS. 


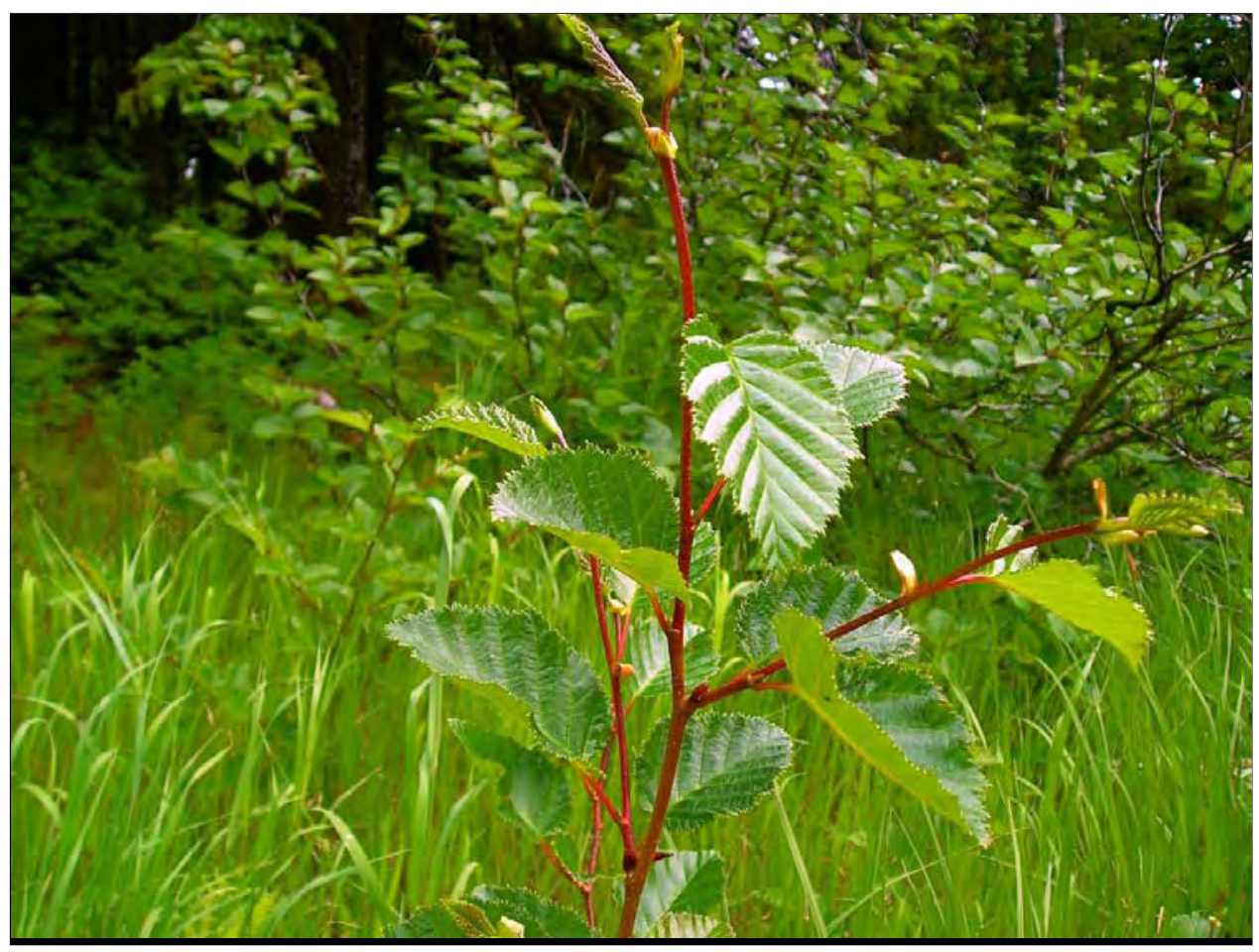

Alders quickly colonized south-central Alaska around 10,000 yr B.P. This shrub is Sitka alder, which is the dominant alder type in coastal regions of southeastern and south-central Alaska.

Photo by Dr. Thomas Ager, USGS. 


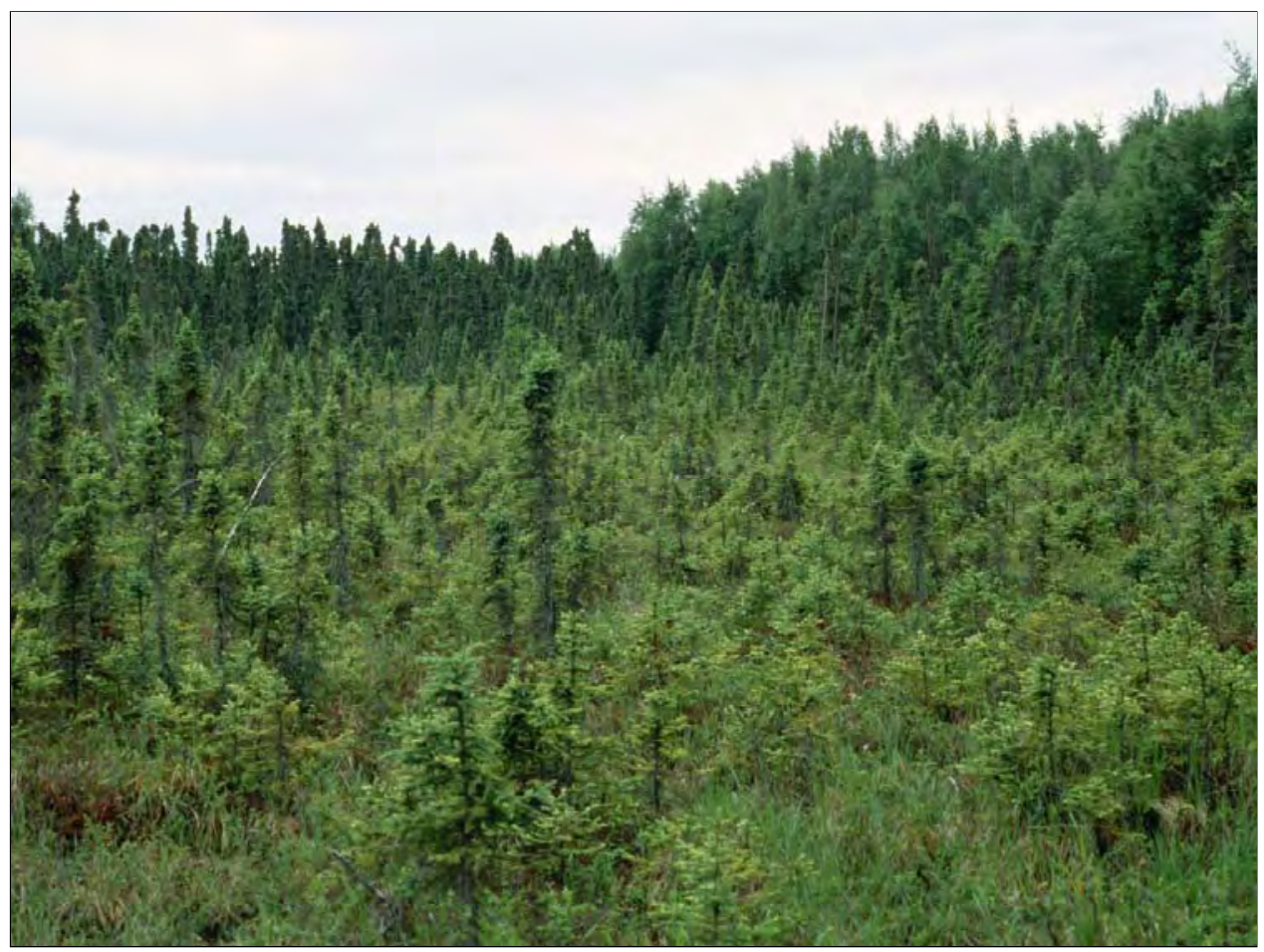

Black spruce colonizing peat bog in Anchorage lowland near Earthquake Park, upper Cook Inlet. Larger trees growing on welldrained ridges adjacent to the bog include white spruce trees and deciduous trees such as balsam poplar and paper birch.

Photo by Dr. Thomas Ager, USGS. 


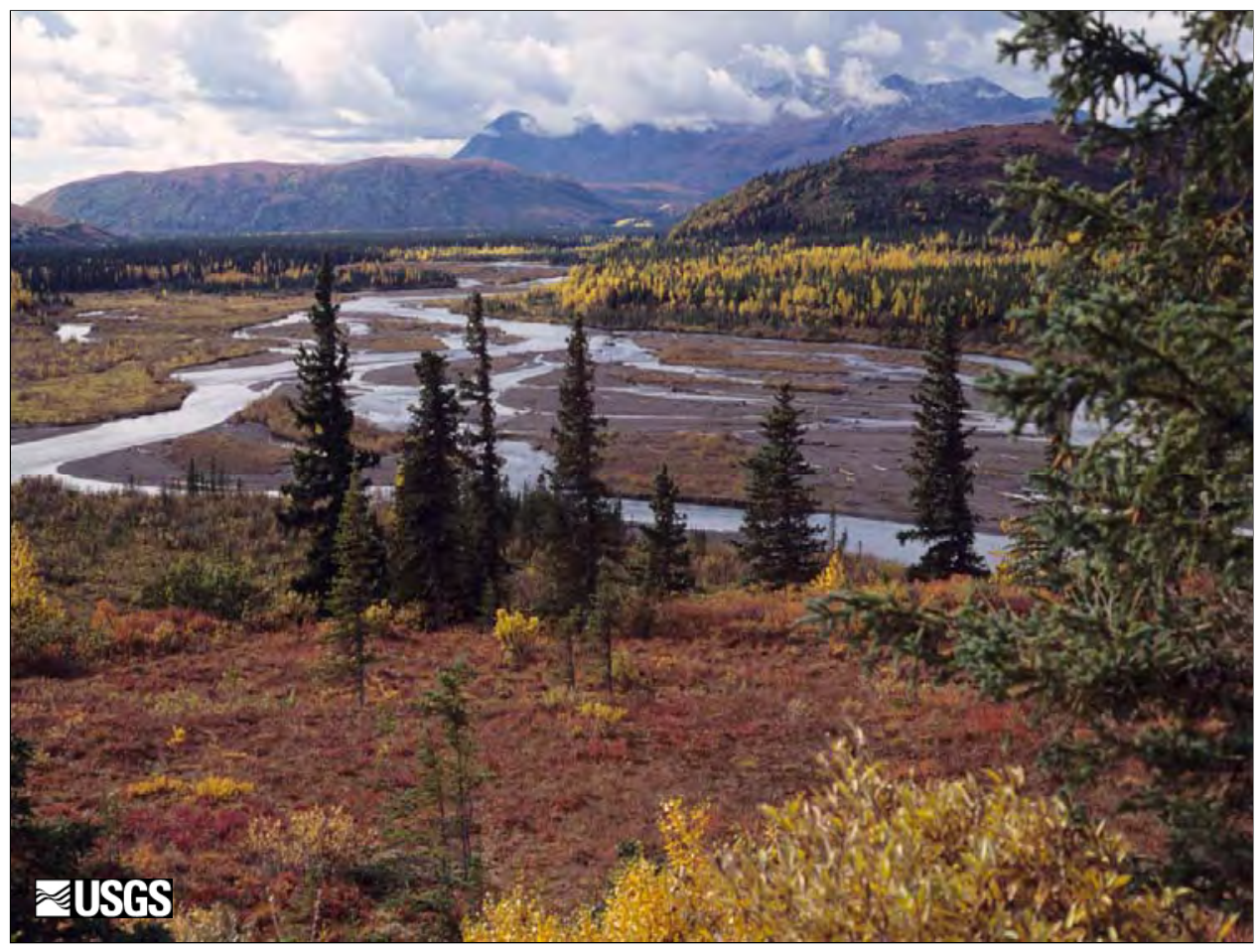

Boreal forest in south-central Alaska in September. Boreal forest vegetation colonized upper Cook Inlet by about 8,800 yr B.P.

Photo by Dr. Thomas Ager, USGS. 


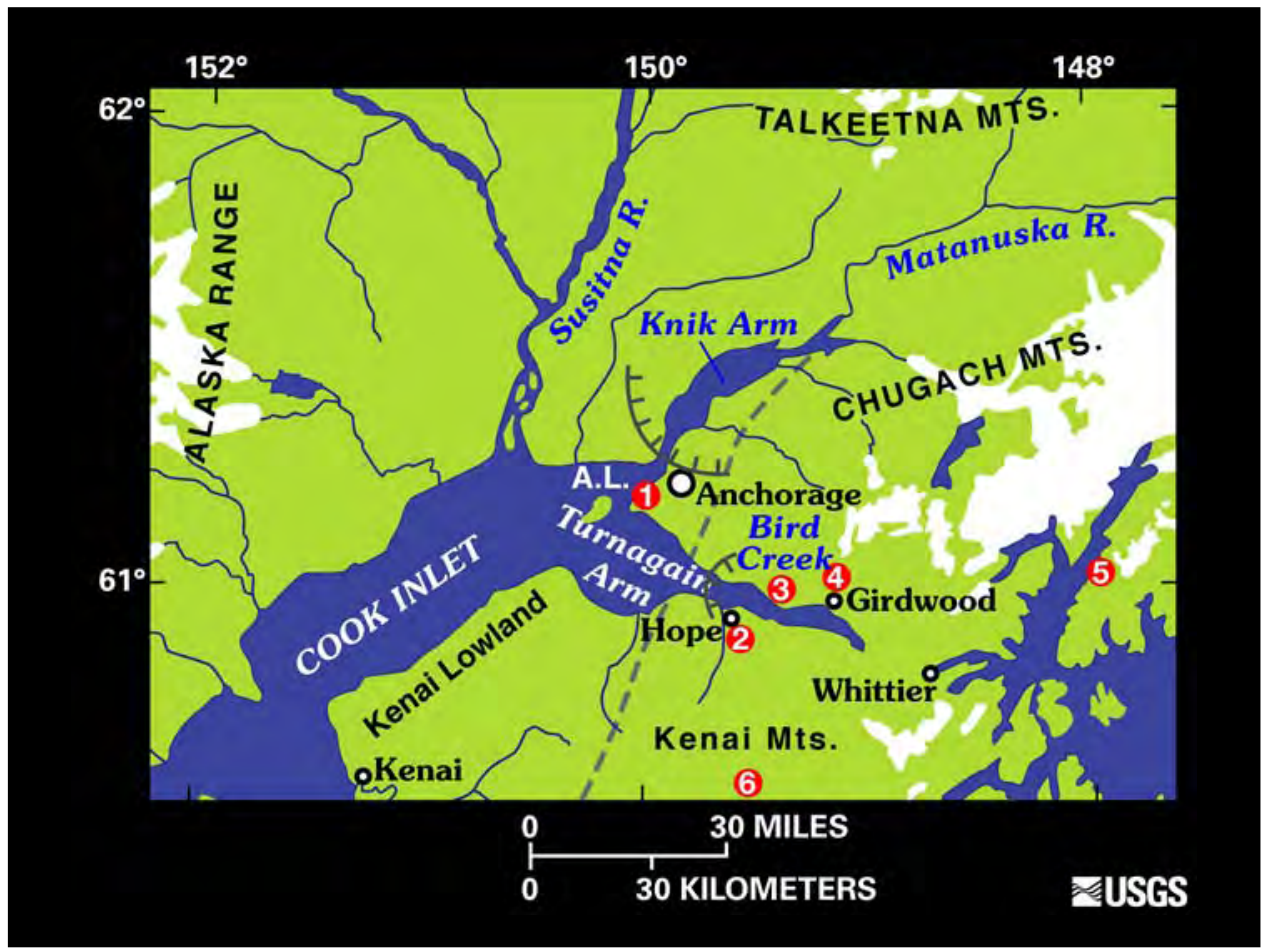

Map of upper Cook Inlet region today, showing position of pollen records from eastern Turnagain Arm (Girdwood, site 4). In contrast to the Anchorage lowland, which has a relatively cool and dry climate, the upper Turnagain Arm area has a much wetter and somewhat warmer climate. These varied climate conditions have influenced the history of vegetation development in the region following deglaciation. 


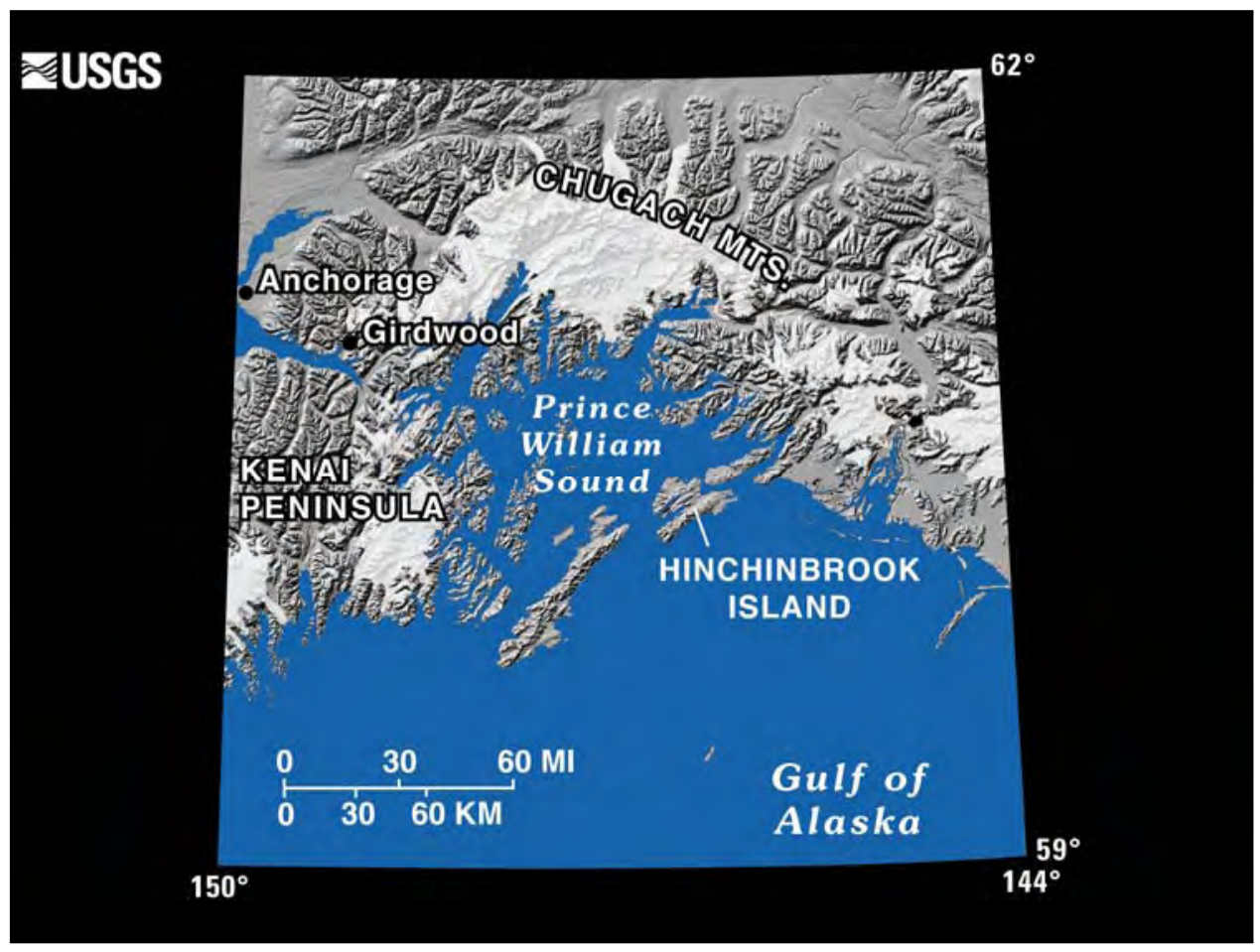

Map of Prince William Sound and vicinity. Ongoing research in this region involves pollen analysis of peat cores obtained from bogs from sites scattered across this map area. 


\section{Turnagain Arm}

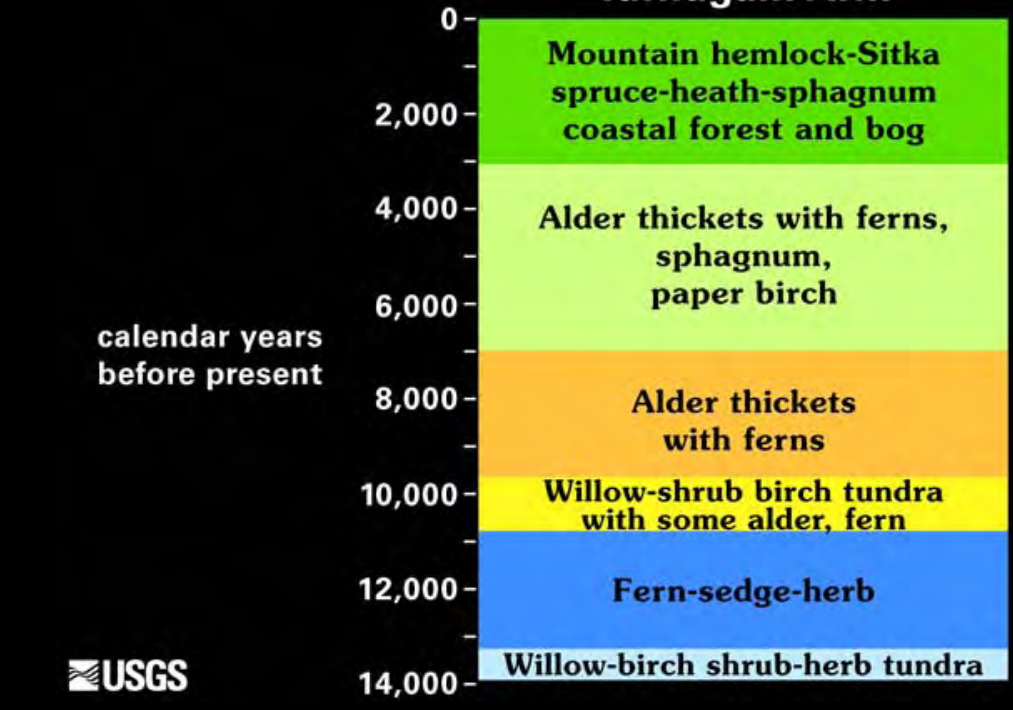

The maritime climate of eastern Turnagain Arm did not favor colonization by boreal forest vegetation. Following deglaciation about $14,000 \mathrm{yr}$ B.P., herb-shrub tundra vegetation was the initial colonizer following glacial retreat, followed by alders during the early Holocene. Forestation in eastern Turnagain Arm was delayed until the late Holocene (ca. 3,000 yr B.P.), when mountain hemlock and Sitka spruce migrated into the area from the east.

Chart based on data obtained by Dr. Thomas Ager, USGS. 


\section{Mean Annual Precipitation Along a West to East Transect}

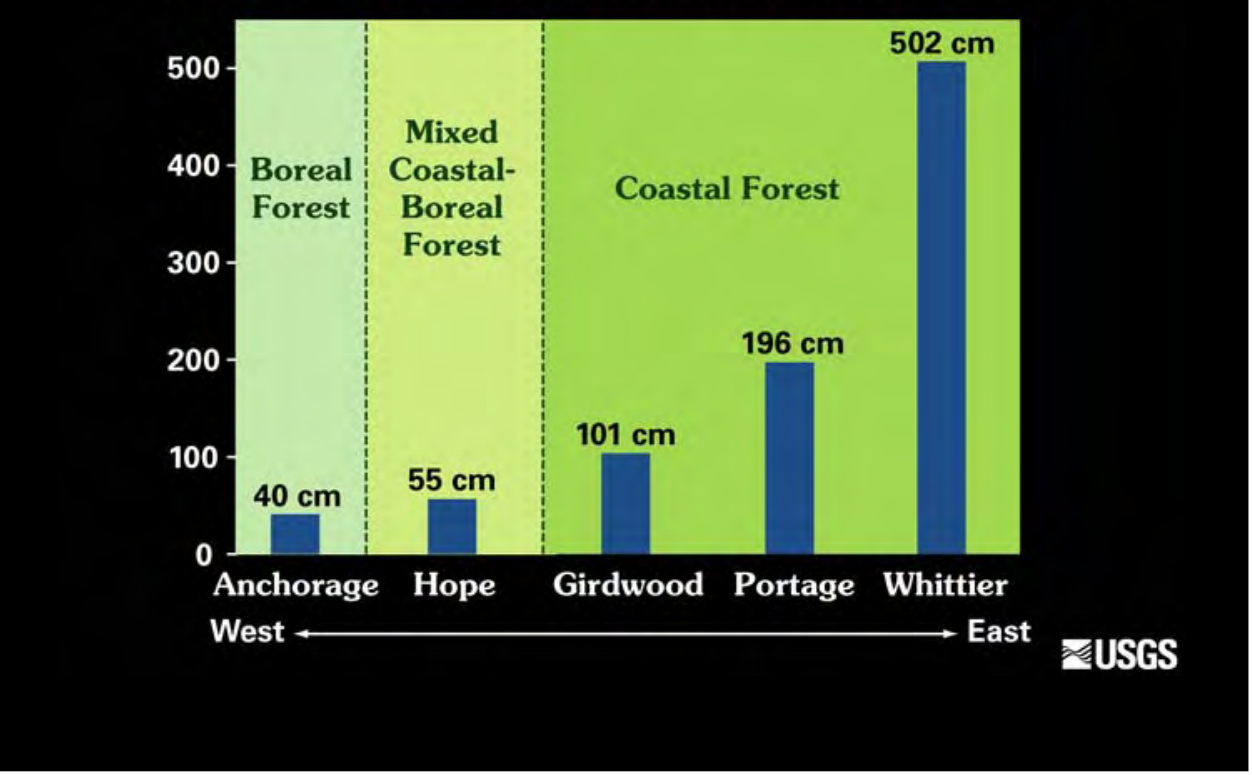

Comparison of mean annual precipitation in a west to east transect from Anchorage lowland to northwestern Prince William Sound. Boreal forest vegetation occurs where precipitation is low (a result of precipitation shadows inland from coastal mountain ranges). Pacific coastal forest and alder thickets occupy areas with high precipitation and milder winter temperatures. 


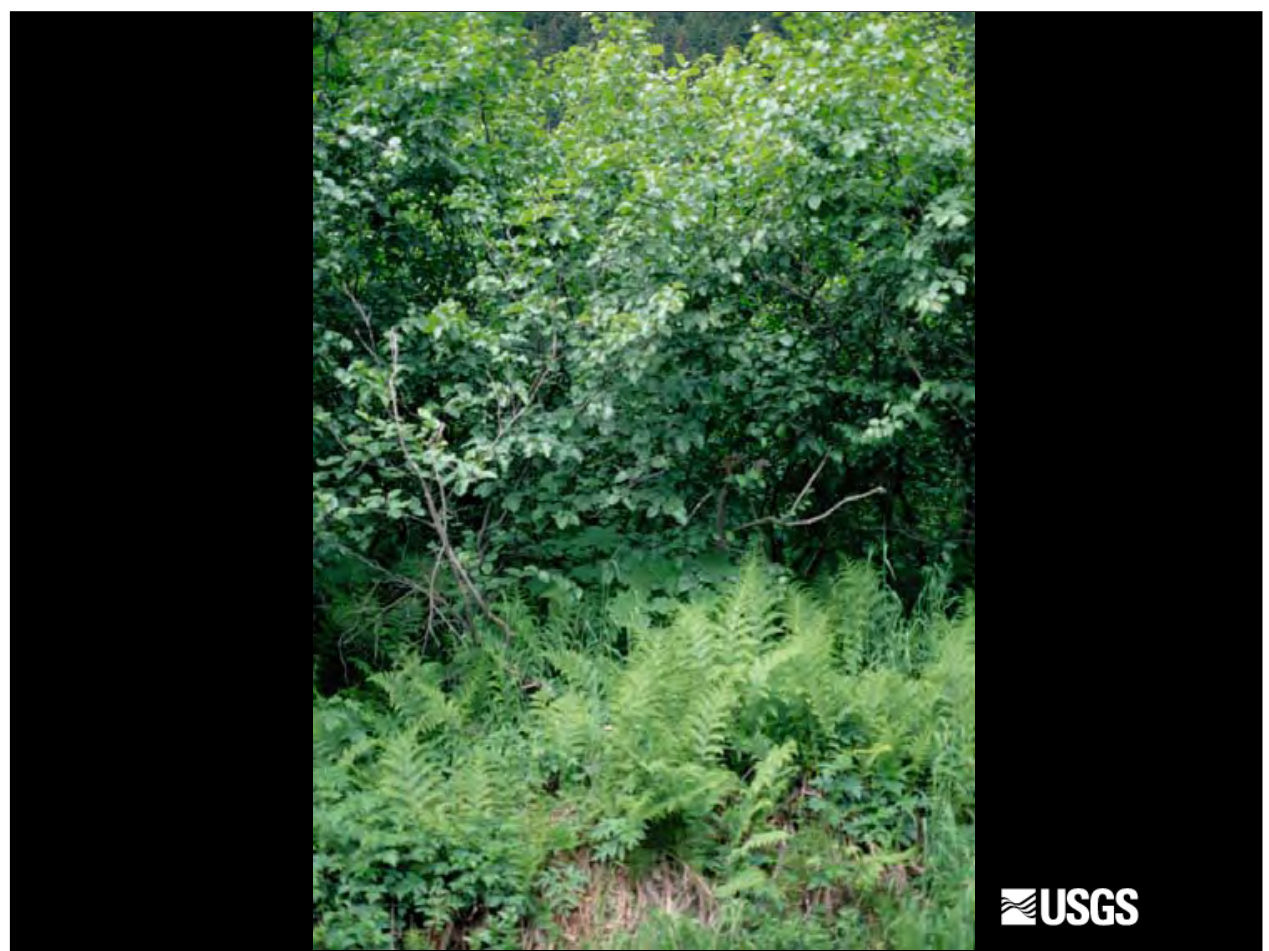

Sitka alder and abundant ferns colonized much of south-central Alaska during the early Holocene, particularly along the coast. In many areas, alders and ferns were dominant elements of the vegetation until they were partly displaced by expanding coastal forests of mountain hemlock and Sitka spruce during the past 3,200 years.

Photo by Dr. Thomas Ager, USGS. 


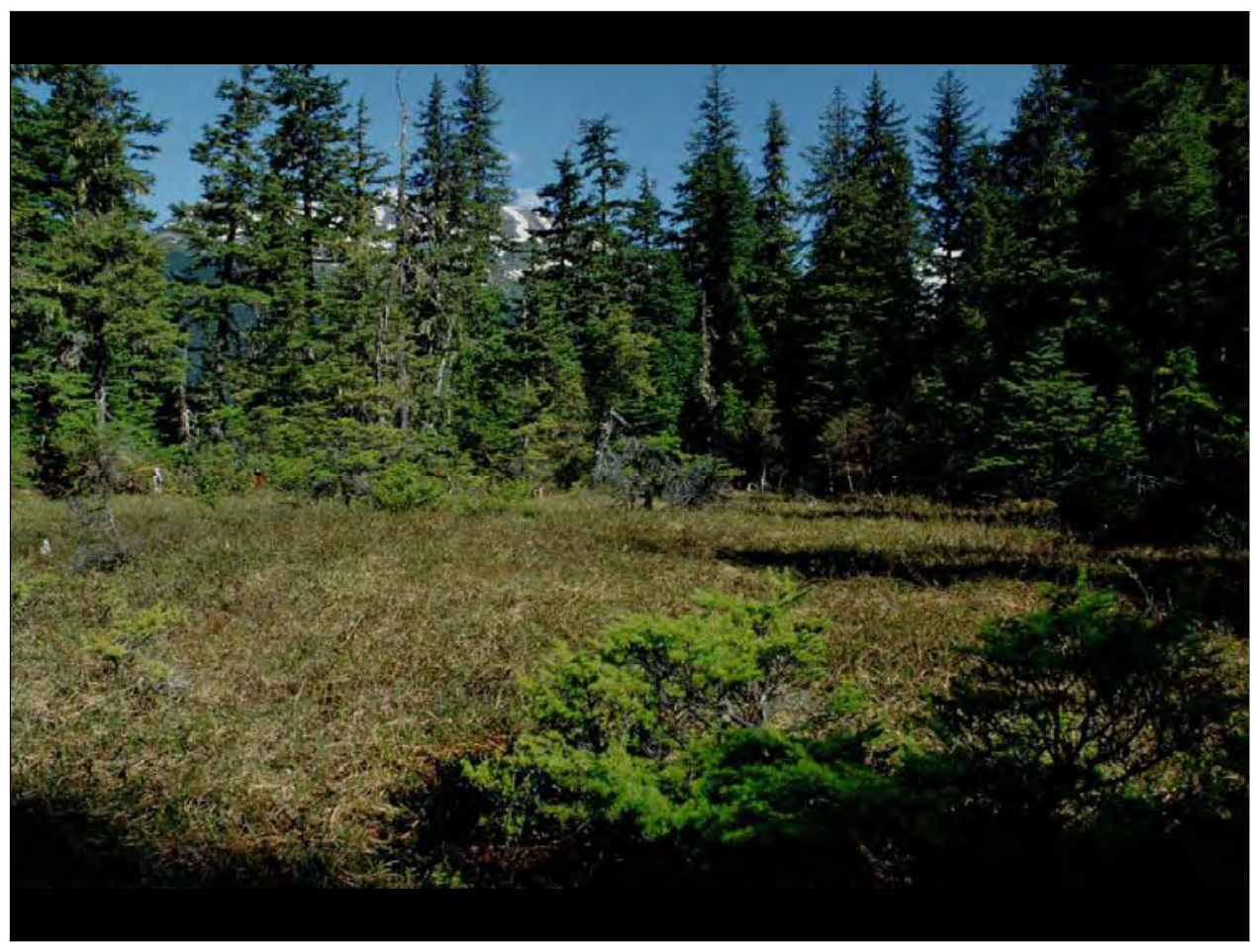

Mountain hemlock and Sitka spruce forest grow in eastern Turnagain Arm and adjacent Prince William Sound. Mountain hemlocks growing in peat bogs and muskegs tend to form slow-growing, stunted forms, such as those seen in the foreground. From the time of deglaciation to the establishment of coastal forest in this region, about 11,000 years elapsed. Vegetation change in response to climate change can be slow if there are no nearby seed sources of plants that are adapted to the new climatic conditions. Photographed near Girdwood in upper Turnagain Arm.

Photo by Dr. Thomas Ager, USGS. 


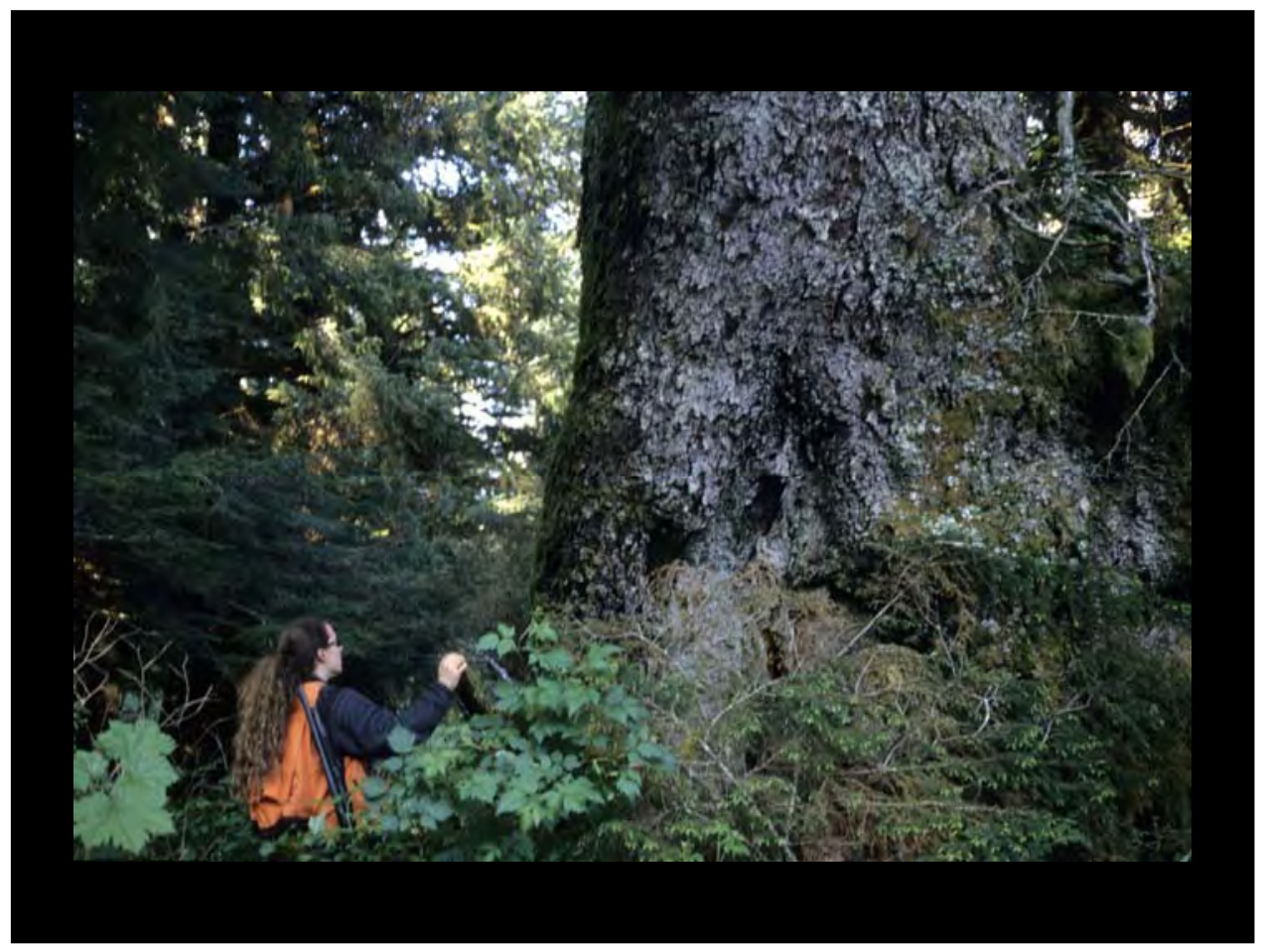

Sitka spruce can attain ages of 600 years or more and sometimes grow to awe-inspiring size. This tree and many others like it were seen on southwestern Hinchinbrook Island in Prince William Sound. Although coastal forest vegetation has been established in some areas of southcentral Alaska for about 3,000 years, other areas suitable for the growth of trees are still unforested. The process of colonization of coastal areas by forest vegetation is still underway in many areas. Late-arriving trees such as western hemlock and yellow cedar have colonized only limited areas of the south-central Alaskan coast and will continue to spread westward.

Photo by Dr. Thomas Ager, USGS. 